\title{
A Review of the Amphipod Genus Corophium, with Notes on the British Species.
}

\author{
By
}

\section{G. I. Crawford, M.A.,}

Assistant-Keeper at the British Museum (Natural History) : late Student Probationer at the Plymouth Laboratory.

With 4 Figures in the Text.

\section{Contents.}

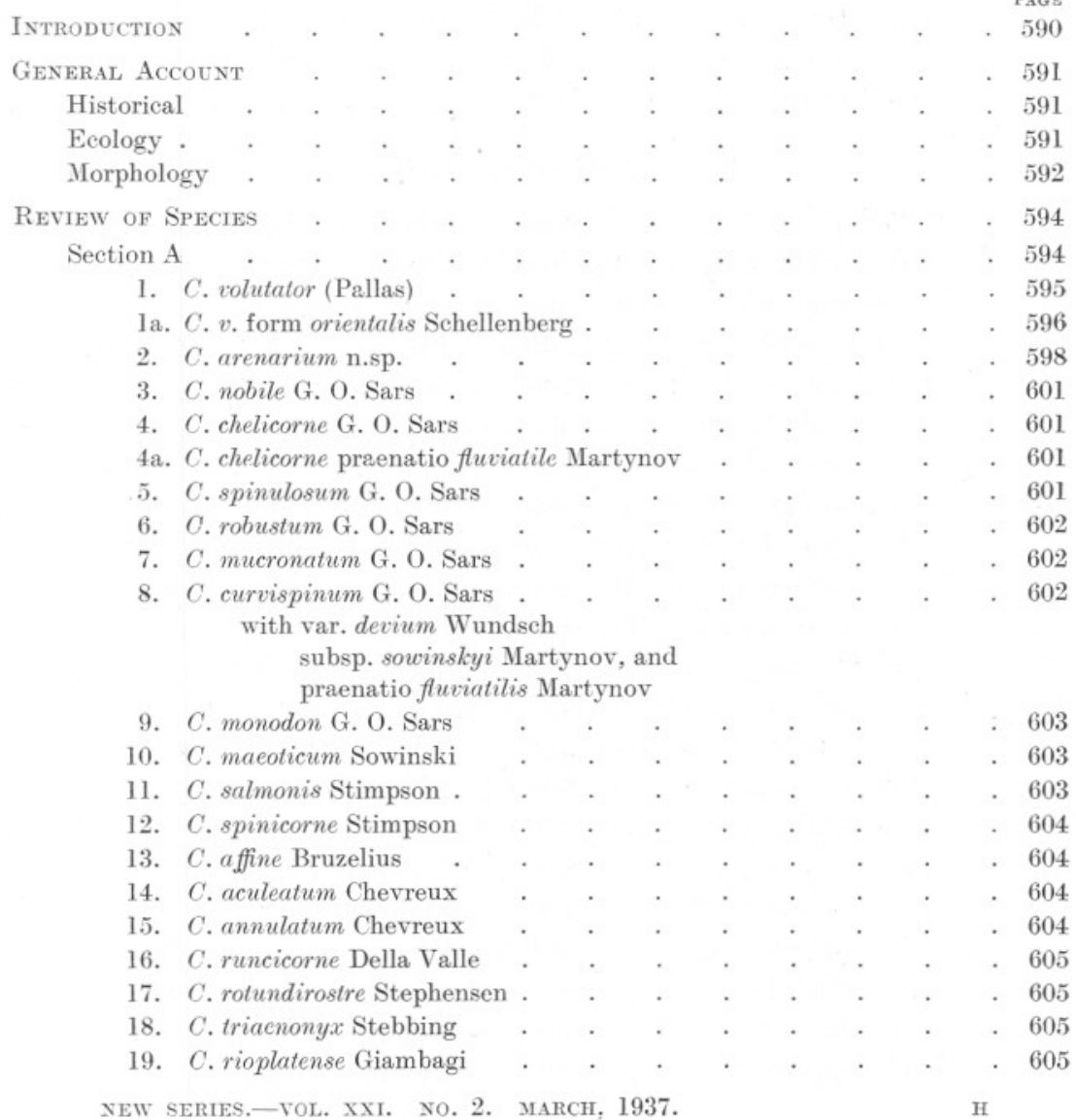




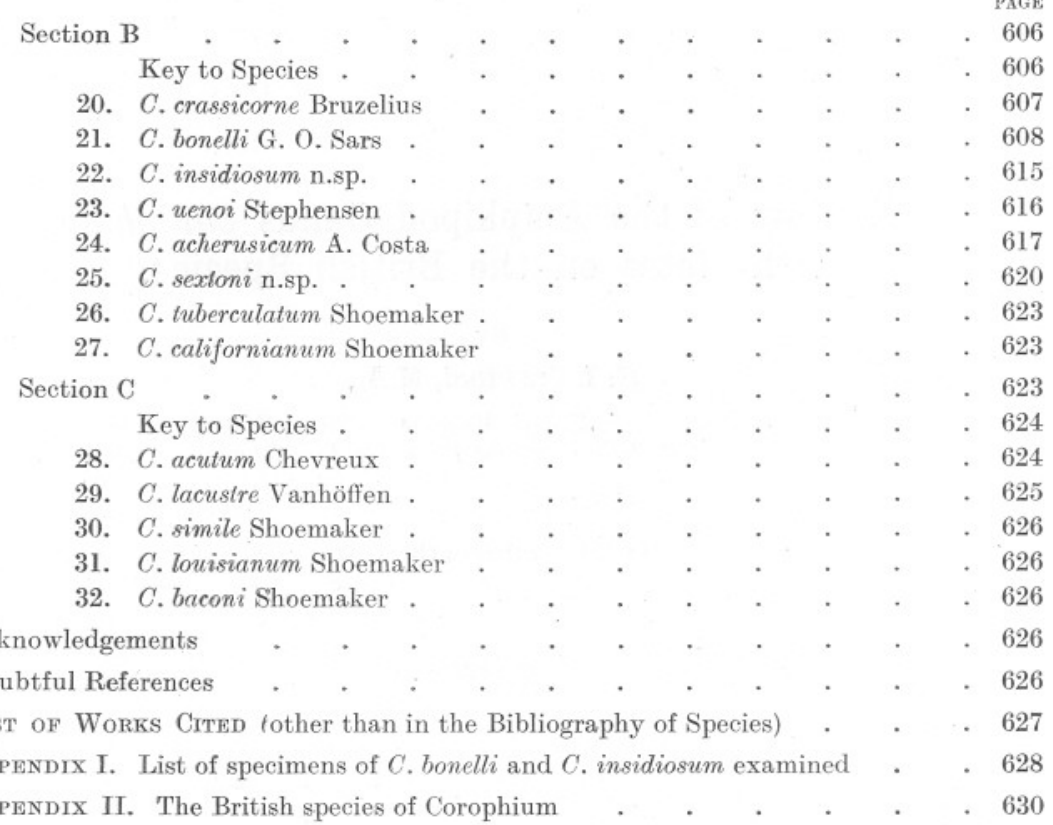

\section{INTRODUCTION.}

During 1934-5 I collected in Plymouth Sound and neighbouring waters seven species of the genus Corophium of which two were undescribed. I also collected one other species, and had sent to me two other species (one new) from other localities in South England. A list of these ten species, with the single other species known from Britain, is given in Appendix II, and their British distribution summarized.

In the course of identifying them I examined 23 of the 32 species of Corophium, and saw all the literature to which I could find references.

The first part of this paper consists of a general account of the morphology and ecology of the genus and a key by which it can be divided into three sections. This part is introductory to the second part, which contains a review of those species which I consider valid. In this review the name of each species is followed by a complete bibliography, only those references being omitted which have already been listed by Stebbing (1906) : if a number of references have been made to a species, that which contains the best description or figures is placed in square brackets above the others, and immediately below the name of the species. An account of distribution follows the bibliography, and is followed for many species by notes on ecology and identification.

Description and figures are given of the three new species: and keys have been made to two of the sections (13 spp.). Holotypes and paratypes of new species are in the British Museum (Natural History). 


\section{GENERAL ACCOUNT.}

\section{Historical.}

The genus Corophium was established by Latreille in 1806, to include the single species $C$. longicorne (which had previously been described as Oniscus volutator Pallas).

The best general account is that of Stebbing (1906), who defines the genus, and gives a key to 12 species, with descriptions and full bibliography. Bradley (1908) gives a key to 15 species (not 16 as appears, for $C$. cylindrioum and $C$. acherusicum are synonymous), and excellent figures and descriptions of $C$. salmonis and $C$. spinicorne. He does not describe the other species, or list bibliography, and his key is inferior to Stebbing's. Both these accounts need revision, since the number of species has since been doubled.

Many fauna lists of separate areas have been published. The following are the most important.

Della Valle (1893), 3 spp., Naples.

Sars (1894), 4 spp., Norway.

Sars (1895), 6 spp., and (1896), 1 sp., Caspian Sea.

Chevreux (1908), 3 spp., Bône, Algeria.

Chevreux and Fage (1925), 6 spp., France.

Stephensen (1929), 5 spp., Nord und Ost-See.

Shoemaker (1934 a), 9 spp., E. coast of N. America.

Shoemaker (1934 b), 2 spp., W. coast of N. America.

The bionomics of C. volutator are described by Hart (1930); and those of $C$. insidiosum n.sp. by Ussing (1924) under the name of $C$. bonelli.

\section{ECOLOGY.}

As far as is known all species form tubes of mud or muddy sand, either in the substratum or upon ascidians, sponges, etc. These two habitats are each frequented by about half the species of Section A, as defined below, but with the exception of $C$. crassicorne in Section B no species of the other sections is known to burrow. The tubes of $C$. volutator and C. insidiosum are described respectively by Hart (1930) and Ussing (1924).

The species of this genus are found in shallow water, and frequently between tidemarks. They are characteristic, especially the species which build tubes on sessile objects, of harbours and estuaries, where there is much silt for the forming of tubes. Many are able to endure slight diminutions of salinity in the surrounding water, and a few species live in fresh, or nearly fresh, water. C. rioplatense was described from specimens found in fresh water in the Rio de la Plata, C. spinicorne has 
been found in the San Francisco water supply, and C. curvispinum var. devium is common in the freshwater reaches of many European rivers.

The feeding of $C$. volutator is described by Hart (1930). This species is principally a selective deposit feeder, and also consumes a small proportion of suspended particles. The form of the limbs chiefly used in feeding-the maxillipedes and the two pairs of gnathopods-is so constant throughout the genus that it is probable that other species differ only in the proportions of the focd-supply drawn from these two sources.

In the British species (except for $C$. bonelli) both sexes are usually present in collections, though the female is usually rather commoner than the male: and this appears, from the literature and specimens that I have seen, to be so with most species of the genus. C. bonelli, however, is almost certainly parthenogenetic - a condition rarely found elsewhere in the Amphipoda. The evidence on which I base this conclusion is summarized in the account of that species.

Some species, e.g. C. acutum, are almost world-wide in distribution. Species which build tubes on sessile objects are clearly likely to be carried by shipping, and $C$. acherusicum has been collected off a ship's bottom at Sheerness.

\section{MorPHOLOGY.}

A full definition of the genus is given by Stebbing (1906). The features most characteristic of the genus are the second antennae, the mandibular palp (which is 2-jointed), and both pairs of gnathopods. In the male antenna II, segment 4 is normally stout and terminates with a single or complex tooth: this segment may also bear spines. In many species of Section A this segment is similar in the female to that of the male: in others, and in almost all species of Sections B and C, this segment in the female bears no teeth, but only spines, the arrangement of which is specifically distinctive. These features are well shown in the drawings of Sars (1894), whose general account of the genus on pages 612-3 is also excellent.

The genus may be divided into three sections on the characters of the urosome: no spécies are known with intermediate characters.

Section A : segments of urosome separate (19 spp.-10 accepted by Stebbing in 1906).

Section B : segments of urosome fused; uropods I and II inserted in notches in the lateral margins of the urosome $(8 \mathrm{spp}$.2 accepted by Stebbing).

Section C: segments of urosome fused; uropods I and II attached ventrally; lateral margins of urosome without notches (5 spp.-none known to Stebbing). 
The fusion of the segments of the urosome has proceeded further in Section C than in Section B, and therefore the species of Section C seem to have developed most, and those of Section A least, from their hypothetical common ancestor. Fusion of the urosome segments is not common in the Amphipoda. The characters of these sections are further considered in the appropriate place in the review of species.

Certain species have frequently been confused with each other, especially C. crassicorne, C. bonelli, $C$. insidiosum, and C. acherusicum, and to a less extent C. acutum and C. lacustre. This is due to incomplete knowledge of distribution and of literature, and even more to attention wrongly paid to characters which are not specific.

For identification, adult specimens (ovigerous ç and $\hat{\jmath} \widehat{o}$ therewith) of both sexes should be examined, and the following features observed: form of rostrum, eye-lobes, eyes ; antenna I, form of basal segment and arrangement on it of outgrowths, spines and setae, ratio of lengths of first three segments, number of segments in flagellum; antenna II, segments 4 and 5, form of segment and arrangement of spines, teeth or processes, and density and length of setae; gnathopod I, form of palm, spines on it, and subsidiary teeth on dactyl ; gnathopod II, subsidiary teeth on dactyl; pereiopcds 5 and 6 , spines on carpus; pereiopcd 7 , form of basal segment and ratio of its length to that of propod; urosome, segments separate or fused, and shape of lateral margin; uropods I and II, spines on peduncle and rami; uropod III, form of ramus; telson, form.

Of these the characters of the urosome; of antenna I, segment 1; and of antenna II, segments 4 and 5, are the most useful. The gnathopods, though very characteristic of the genus, and not similar in form in every species, are usually very similar in related species. The mouth-parts are very uniform, as far as is known.

The characters of the antennae change with age, and even in adults some variation occurs. Variation in C. curvispinum is described by Wundsch (1915), in C. salmonis and C. spinicorne by Bradley (1908), and in C. volutator by Hart (1930). In this paper I have described variation in C. arenarium, C. bonelli, C. insidiosum, C. acherusicum, and C. sextoni. In these, and in C. crassicorne, the antennae of juveniles are shorter in relation to the body; the segments are stouter, and bear more spines in the male and less in the female. The adult male in these five species bears only a few small spines on the antennae. Outgrowths on antenna I, segment 1 , and antenna II, segment 5 , which are characteristic of the males of some species, are only present in full-grown specimens: the same is true of the very long rostrum of the adult male of $C$. aculeatum, C. insidiosum, and C. uenoi.

The number of segments on the flagellum of antenna I, of subsidiary 
teeth on the dactyl of gnathopod II, and of spines on the uropods increases with age.

Measurements of length given in this paper are from rostrum to telson.

\section{REVIEW OF SPECIES.}

\section{SECTION A.}

This section contains 19 species, of which one is here described as new. I have examined 13 of these, the remaining six being $C$. spinulosum Sars, C. maeoticum Sowinsky, C. salmonis Stimpson, C. spinicorne Stimpson, $C$. rotundirostre Stephensen, and $C$. rioplatense Giambagi.

I have not made a key to the section, since the specific differences do not lend themselves to the necessary terse description, and adequate figures have been published of every species. Stebbing (1906) included a key to 10 species with full synonymy and description. Bradley (1908) gave a key to 13 species, with the synonymy, descriptions and figures of C. salmonis and C. spinicorne only. His key is not, however, of great use as he relied on characters common to both sexes and these are not well known or distinctive.

In about half the species segment 4 of antenna II in the female differs from that of the male only in being less strongly developed. Several are of large size $(8-12 \mathrm{~mm}$.) compared with those of Sections B and C. C. rioplatense, C. curvispinum var. devium, and C. spinicorne have been found in fresh water ; and many other species inhabit water of low salinity. The majority of species for which information is available are burrowers. Most are restricted in distribution in comparison with those of Sections B and C.

The type species of the genus is $C$. volutator Pallas, which is recorded from Europe (including the Sea of Azov) and the Eastern coast of North America. It bears much resemblance to $C$. arenarium from England and North France, a species here described as new; to C. salmonis and C. spinicorne from California; to $C$. maeoticum from the Sea of Azov ; and to C. nobile, chelicorne, spinulosum, robustum, mucronatum, curvispinum, and monodon from the Caspian Sea and neighbouring waters. In all these species (except C. arenarium) antenna II, segment 4, differs little in the two sexes, and in many of the species from the Caspian Sea and Sea of Azov this segment bears a complex armature of terminal teeth. All are at least of moderate size and many are large (4-12 mm.).

C. aculeatum, C. annulatum, and C. runcicorne from the Mediterranean, with $C$. affine from the North Sea and Arctic seas, form a natural group of rather small burrowing forms $(1.5-5 \mathrm{~mm}$.) of slender build, and with uropod III linear in shape. The only known specimens of $C$. rotundirostre (also from the Mediterranean) have antenna II missing ; it is not, there- 
fore, known if this species resembles the other four in having antenna II, segment 4, unlike in the sexes. In other features it is rather similar to C. annulatum, though much larger.

C. triaenonyx from Ceylon and $C$. rioplatense from fresh water in the Rio de la Plata are two non-burrowing species of moderate size (3-4 mm.). The form of antenna II, segment 4, in the female distinguishes them from each other and from other groups. Probably a better knowledge of surrounding regions would reveal species related to them.

\title{
1. Corophium volutator (Pallas).
}

\author{
[Sars, G. O., 1894, p. 614, pl. 219 as C.grossipes.]
}

1816, C. v., Leach, Encyc. Brit., p. 401. 1821, C. longicorne, d'Orbigny, J. Phys. Chim. d'Hist Nat. Arts, 93, pp. 194-200. 1825, “Corophie à longues cornes," Desmarest, Consid. Gen. Sur. Classe. Crust., p. 270. 1829, "La Corophie longues-cornes," Latreille, in Cuvier's Règne Animal, 4, p. 123. 1840, C. l., Milne-Edwards, H., Hist. Nat. Crust., 3, pp. 66-7. 1857, C. v., White, Pop. Hist. Brit. Crust. 1859, C. l., Bruzelius, Svensk. Ak. Handl., N.S., 3, No. 1, p. 14. 1862, C.l. (part-the specimens found with Jassa falcata are probably some other sp.), Bate, Cat. Brit. Mus., p. 280, pl. 47, f. 4. 1863, C. l., Bate, Brit. Sess. Eyed Crust., 1, p. 493. 1869, C.l., Brady. Nat. Hist. Trans. Newcastle, 3, p. 120. 1873 , C. l., Parfitt, Trans. Devon. Ass. F. Devon, 9, p. 13. 1874, C. l., and ? C. bonelli, Bos, Biol. Crust. Hedriopth. Ned., pp. 28, 52. 1879, C. l., Hoek, Tijdschr. Ned. dierk. Ver., 4, p. 115. 1884, C. l., Blane, Nova Acta. K. Leop. Carol., 47, No. 2, pp. 82-85, f. 102-114. 1885, C. . ., Gadeau de Kerville, Estuaire de la Seine, 2, p. 181, Havre. 1886, C. grossipes, Herdman, 1st Rep. Liverp. Bay. 1888, C. v., Robertson, Trans. Nat. Hist. Soc. Glasg., 2, p. 61. 1889, C. g., Hoek, Tijdschr. Ned. Dierk. Ver., Ser. 2, 2, p. 230, pl. 8, f. 4-8. 1898, C. v., Sowinski, Bull. Acad. Sci. St. Pétersb., Ser. 5, 8, p. 361. 1901, C. g., Elliott, F. Fl. and Geol. Clyde Area, p. 342. 1901, 1903, C. g., Allen and Todd, J. Mar. Biol. Assoc., 6, pp. 151, 295. 1906, C. g., Scott, Proc. R. Phys. Soc. Edinb., 16, pp. 172, 379. 1906, C. l., Sinel, Trans. Soc. Nat. Sci. Guernsey, p. 212. ? 1906, C.l., Sinel, Outline Nat. Hist. our Shores, p. 119. 1906, C. v., Norman and Scott, Crust. Devon and Cornwall, p. 95. 1906, C. v., Stebbing, Das Tierreich, 21 (1), p. 686. 1907, C. g., Colgan, Irish. Nat., 16, p. 181. 1907, C.g. (part), Gurney, Trans. Norfolk. Norw. Nat. Soc., pp. 414, 417, 421, 427 (part), 435 (part), table II (part) (see also C. lacustre). 1907, C. v. Norman, Ann. Mag. Nat. Hist., Ser. 7, 20. 1907, C. l., Patterson, Wild Life on a Norfolk Estuary, p. 223. 1908, C. v., Bradley, Univ. Cal. Publ. Zool., 4, p. 229. 1911, C. v., Chevreux, Mem. Soc. Zool. Fr., p. 270. 1914, C. v., Stubbs, Zoologist (4), 18, p. 54. 1918, C. g., Hellen, Medd. Soc. Fauna Fl. Fennica, 45, p. 136. 1920, C. v., Mercier, C. R. Acad. Sci., 170, p. 410. 1922, C. l., Flattely and Walton, Biology of the Seashore (London), p. 167. 1922, C. g., Tesch, Fl. and Fauna Zuiderzee, p. 335, f. 7. 1923, C. v., Schlienz, Arch. Hydrobiol. Plankt., 14, p. 429. 1925, C. v., Chevreux and Fage, F. de France, 9, p. 364, f. 372. 1926 , C. v., Legueux, Bull. Soc. Linn. Normandie, Ser. 7, 8, pp. 93-4. 1926, C. v., Poisson and Legueux, Bull. Soc. Zool. Fr., p. 322. 1926, C. v., Ranson, C. R. Socs. Sav. Paris and Dep., p. 413, f. 1. 1927, C. v., Stephensen, Vidensk. Medd. Naturh. Foren., 84, p. 139. 1929, C. g., Gurney, Trans. Norfolk. Norw. Nat. Soc., 12, p. 550. 1929, C. g., Percival, J. Mar. Biol. Assoc., 16, p. 81. 1929, C. v., Stephensen, Zoology of Faroes, Copenhagen, XXIII, Marine Crustacea Amphipoda, pp. 1-40. 1929, C. v., Stephensen, Die Tierwelt der Nordund Ostsee, 14, x. f., p. 168-9, f. 40. 1930, C. v., Hart, Trans. Norfolk. Norw. Nat. Soc., 13, p. 32-3. 1930, C. v., Hart, J. Mar. Biol. Assoc., 16, p. 761, f. 1-4. 1930, Corophium, Lambert, Proc. Zool. Soc. Lond., p. 801. 1930, C. v., Trusheim, Senckenbergiana, 12, p. 254, f. 1-3. 1931, C. v., Elmhirst, Proc. Roy. Soc. Edinb., 51, No. 21, p. 171. 1931, C. v., Schijfsma, Tijdschr. Ned. Dierk. Ver., Ser. 3, 2, p. 168. 1932, C. v., Elmhirst, Glasg. Nat., x, No. 2, pp. 56-62. 1933, C. v., Nicol, Dove. Mar. Lab. Rep., Ser. 3, No. 1, p. 51. 1934, C. v., Serventy, Norf. Norw. Nat. Soc., Scolt Head Island, pp. 204-5. 1934, C. v., Shoemaker, Proc. Biol. Soc. Wash., 47, pp. 23-4. 1935, C. v., Nicol, J. Mar. Biol. Assoc., 20, p. 203. 
Distribution. Europe: Ireland, Scotland, England, Wales; W. Norway, the Baltic; European coasts to the Adriatic; Sea of Azov. America: Maine (in stomach of a duck); Bay of Fundy.

C. volutator is the type species of the genus, and is by far the most familiar and frequently collected. Its ecology is treated by Hart (1930).

It is frequently very abundant, forming tubes intertidally in the mud of estuarine mud-flats, salt-marsh pools, and brackish ditches. In some of the streams running into the Tamar it lives in almost fresh water associated with a number of insect larvae, e.g. Calopteryx splendens (Dragonfly). In many of its localities, however, the water is nearly of full salinity.

1a. Corophium volutator form orientalis Schellenberg. 1923, C. v. f. o., Schellenberg, A., Trans. Zool. Soc. Lond., 22, p. 673.

Distribution. Suez Canal. ? Coast of Cirenaica.

Schellenberg's specimens are in the British Museum (1928.9.5, 321325). I am unable to distinguish from them some specimens from Cirenaica, collected by Chaworth Musters (1926.10.28, 15-21).

There are two ovigerous females in Schellenberg's material, and these differ only from $C$. arenarium n.sp., described below, in bearing no spines on antenna II, segment 5 ; these spines are not always present in $C$. arenarium. These females bear two spines on antenna II, segment 4 , not a "spine-like tooth." Further collecting will probably show that C. arenarium is the same as C. volutator form orientalis.

A number of the features remarked on by Schellen.berg as if they were characteristic of his specimens are also present in C. volutator, and in C. arenarium from Leigh-on-Sea and Roscoff. These are : the form of the gland-cone, the proportions of gnathopod II, the presence of toothed ridges on the telson (omitted from Sars' figures of C. volutator, 1894), and the form of the peduncle of urosome III. Stebbing's small-scale drawing of this segment, to which Schellenberg refers, is misleading and much inferior to that of Sars. The only one of Schellenberg's distinctions

\section{EXPLANATION OF FIGURE 1.}

A-C. -ô paratype.

Corophium arenarium n.sp. $\times 52$.

A.-Antenna II.

B, C.-Antenna I, segment 1 from above and from side.

D-I. - 9 holotype.

D.-Antenna II.

E.-Antenna I, segment 1 from above.

F.-Antenna I, peduncle from side.

G.-Uropod I.

H.-Uropod II.

I.-Uropod III. 

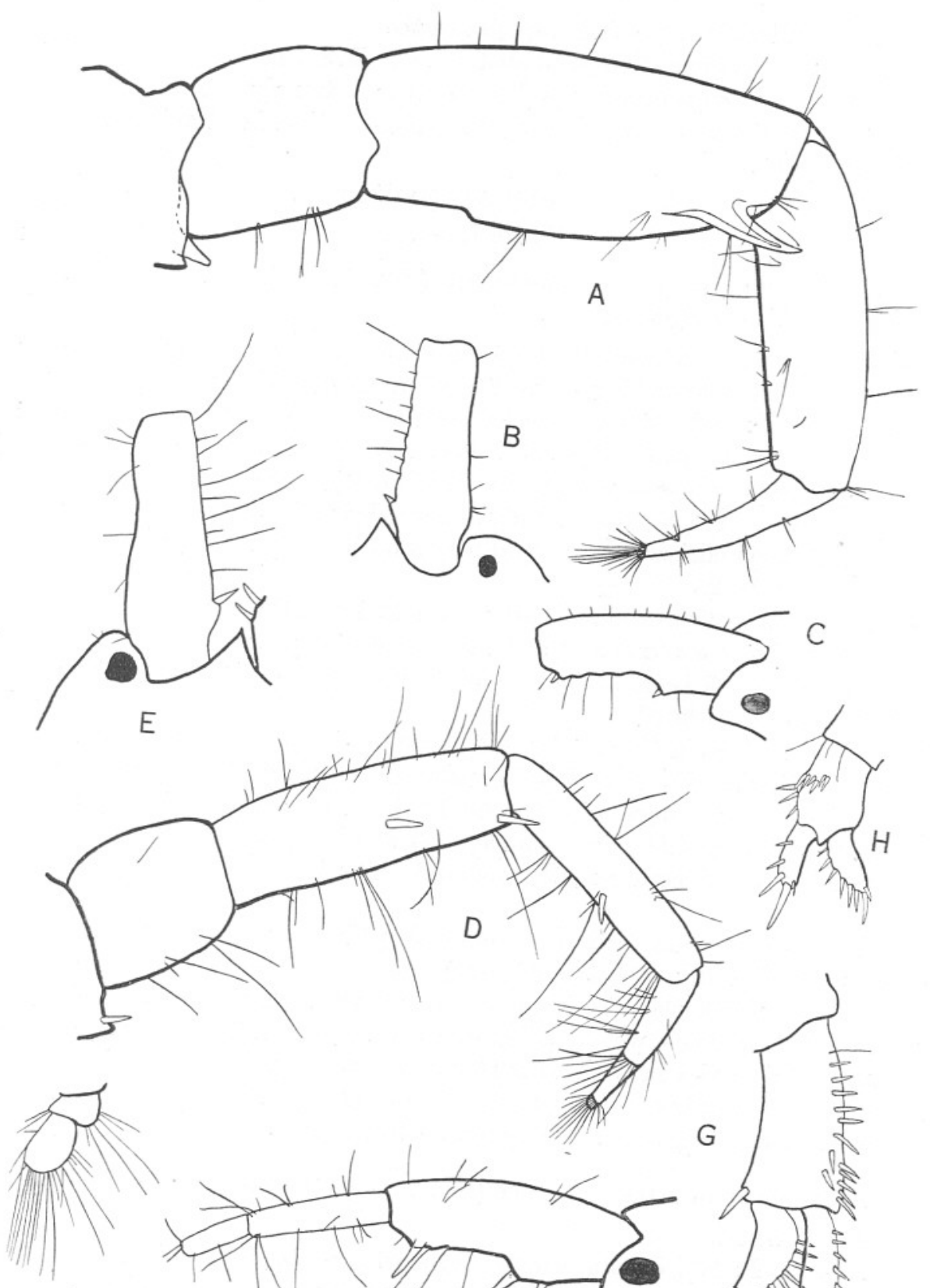

I
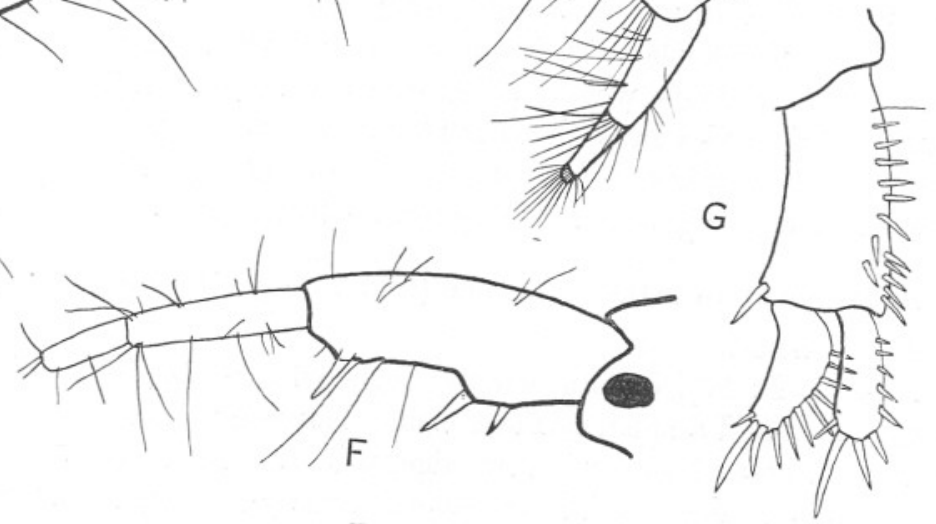

FIG. 1. 
which I find valid is that in his specimens the merus of pereiopod 6 bears only simple, as distinct from ciliated, setae. I also note that in both sexes the lower edge of antenna I, segment 1 is strongly convex, so that this segment appears in side view much stouter than in $C$. volutator or C. arenarium.

\section{Corophium arenarium n.sp.}

Figure 1, A-I.

DESCRIPTION OF FEMALE HoLOtype (Fig. 1, D-I). Leigh-on-Sea, Essex, 3.viii.30, ovigerous.

Length $6 \mathrm{~mm}$. Rostrum in the form of an equilateral triangle. Eyelobes rounded, not reaching to tip of rostrum. Eyes rather small.

Antenna $I$ : $30 \%$ of total length; segment $1>2+3$, lower edge with 2 spines near the base - the edge between these and the terminal spine concave, bearing 3 setae; inner edge with 1 (left) or 2 (right) spines near base, and several long setae distally; outer edge with a few short setae: segment 2, cylindrical, with several long setae; flagellum, 11-segmented $<$ segments $1+2$.

Antenna II : $35 \%$ of total length ; segment 4, cylindrical, with 2 spines on lower edge, one terminally, and one at about $\frac{2}{3}$ of the way to the distal end; segment 5 bears a single spine at the centre of its lower edge; flagellum, 3-segmented.

Mouth-parts as in C. volutator; all the appendages are very similar to those of that species. Gnathopod I, palm nearly straight, making rather less than a right angle with the hind margin of the propod; dactyl simple. Gnathopod II, dactyl simple. Pereiopods 5-6, merus very setose, with front distal corner much produced. Pereiopod 7, basal segment oval.

Urosome segments distinct. Uropod $I$, peduncle with 13 spines on outer edge (distally set in a double row), 1 on inner edge ; rami with 9-10 spines, of which the distal spines are $>\frac{1}{2}$ the length of the ramus. Uropod II, peduncle with 3 spines on the outer edge, and 6 spines continuing this series in a slanting row across the upper surface; inner ramus with 5 spines, outer with 8 . Uropod $I I I$, ramus elongate-ovate, with numerous long setae. Telson terminally rounded.

DESCRIPTION OF Male Paratype (Fig. 1, A-C). Leigh-on-Sea, 3.viii.30.

Length $4 \mathrm{~mm}$.

Antenna $I$ : $40 \%$ of total length; segment $1>2+3$, lower edge with a small basal and a small terminal spine, between which the edge is crenulate and bears 3 setae; inner edge, with a small basal spine, beyond which it is crenulate and bears several setae (in other males, presumably younger, these crenulations are not present), outer edge with scattered 
short setae; flagellum, 9-segmented at least, but mutilated distally (10- or 11-segmented in males from Roscoff).

Antenna II : 70\% of total length; segment 4 with a single long terminal tooth; segment 5, simple, cylindrical; flagellum obscurely 3 -segmented.

Other features as in female.

This specimen is plainly not fully grown. A male from Leigh-on-Sea, collected on June 28th, 1936, measured $5 \mathrm{~mm}$. Antenna I was slightly over $50 \%$ of this length, and had 15 segments in the flagellum; antenna II was slightly over $100 \%$ of the body-length. The spines on the basal segment of antenna I had disappeared.

IDENTIFICATION AND RELATIONSHIPS. This species is certainly very closely related to $C$. volutator, from which all male and some female specimens can scarcely be distinguished except by their smaller size and different habitat. The notes on variation below suggest that it is only a variety of this species. Until, however, further work has been done on the varieties and growth-changes of $C$. volutator the most satisfactory course is to regard $C$. arenarium as a distinct species. M. Chevais of Paris tells me he hopes shortly to publish a paper on these two species.*

VARIATION. The material originally examined consisted of a few males and ovigerous females from Leigh-on-Sea, Essex, collected by Mr. F. J. Lambert in 1930. In the early spring of $1936 \mathrm{M}$. Chevais of Paris sent me large collections from Roscoff. Though the females were as large as the type only six were ovigerous (probably it was too early in the year). On June 28th, 1936, Mr. Lambert kindly conducted me to the type locality, where I was able to study the habits of this form and collect numerous specimens, including 28 ovigerous females of 4-6 mm. length.

The majority of these females closely resembled the type; in others antenna II resembled that of $C$. volutator female, bearing a terminal tooth on segment 4 , and no spines on segments 4 and 5 . The number of specimens belonging to these extreme forms, and intermediates is shown in Table I. The number of segments in the flagellum of antenna $\mathrm{I}$ is given as an index of age : it appears that these differences are not due to growth, but are present in specimens of uniform maturity.

In C. volutator a terminal spine is often present on antenna II, segment 4, in immature females, but never, in my experience, in ovigerous females. Nor, even in immature specimens, have I seen the other spines on segments 4 and 5 which are frequent in $C$. arenarium.

ECOLOGY. On June 28th, 1936, C. arenarium was found burrowing in firm but slightly muddy sand between Ray Gut and the channel running past Leigh Station. Its range extended from about half-tide mark to low water of neap tides. The water which covers these flats

* In " Travaux de la Station biologique de Roscoff.", 
at high tide is practically of full North Sea salinity. I understand from M. Chevais that the conditions at the Plage de Madeira, Roscoff, are similar.

\section{TABLE I.}

Variation of SpInes on Antenna II of C. arenarium.

Antenna II as in type . . . . . .

Antenna II, 2 spines on segment 4,0 on segment 5 .

Antenna II, Segment 4 with median spine and terminal tooth, no spine on segment 5 .

Antenna II, segment 4 with terminal tooth, no spines on segments 4 or 5 (resembled $C$. volutator ㅇ).

$\begin{array}{cc}\text { Number of } & \begin{array}{c}\text { Average and } \\ \text { extreme number } \\ \text { of segments in } \\ \text { Ant. I, flag., as an } \\ \text { index of age. } \\ \text { specimens. } \\ 17\end{array} \\ \begin{array}{c}11 \cdot 6(10-13) \\ 4\end{array} \\ 11 \cdot 2(10-12) \\ 2 & 12 \cdot 0(12) \\ 5 & 12 \cdot 6(11-13)\end{array}$

\author{
Ant. I, flag., as an
}

17

$11 \cdot 6(10-13)$

$11 \cdot 2(10-12)$

$12 \cdot 0(12)$

$2 \cdot 6(11-13)$

At Leigh the number of burrows per sq. m. was in the order of 10 to 100. Above each of these was a slight pile of sand, around which radiated furrows of about $\frac{1}{4}^{\prime \prime}$ in length, made presumably by the second antennae. Internally the burrows were smooth, and coated with a shining brownish secretion. Many were in the form of a $\mathrm{U}$, with vertical arms of $2^{\prime \prime}-4^{\prime \prime}$ in length, the other opening being about $\frac{1^{\prime \prime}}{2}$ from the sand-pile, and not discernible from outside. The animal was generally found about $\frac{1}{2}$ to $\frac{3}{4}$ " below the opening with the sand-pile. Some burrows appeared to be straight and to have no second opening.

Several burrows contained two specimens, always, as far as could be told on the spot, a male and a female. Two pairs which I collected separately each consisted of a large male $(5 \mathrm{~mm}$.) and a smaller female $(4 \mathrm{~mm}$.) with brood pouch lamellae well developed, but not fringed with hairs. I did not record whether large males were ever found alone. During the day's collecting adult females were 3 or 4 times as common as males of comparable size.

In other burrows I found females (never with males) with newly hatched young of about $1 \mathrm{~mm}$. long. These young specimens formed burrows of a few millimetres in length, communicating with that of the parent by minute holes in the smooth lining, usually about $\frac{3}{4}$ " below the sand-pile. The only female found with young which I later examined under a microscope had brood lamellae fringed with long hairs, but was not bearing eggs.

These few observations can give no more than indications of the habits 
of the animal. It scems likely that in the burrows containing couples the males were waiting for the females to moult in order to impregnate them then, since these females had no hairs on the brood lamellae, and so could not carry eggs without first moulting. It appears also from the behaviour of the newly hatched young that the burrows are of some permanence. Presumably the young must become independent of the female at latest by the time of her next moult.

Thamdrup (1935) gives a more detailed description of this type of tube, made in sand between tidemarks on the Danish coast (pp. 40, 41, 47, Figs. 12-16), and compares it with the ordinary tube of $C$. volutator (p. 47, Fig. 20), which he also found, but not in the same areas. His observations on the presence of pairs of adults, and of young, in these tubes agree with mine but are more complete. He does not remark on any morphological differences between the inhabitants of these two types of tubes. I have not been able to examine his specimens, but I think that he must have found both species.

\section{Corophium nobile G. O. Sars.}

[Sars, G. O., 1895, p. 292, pl. 20, 21.]

1906, C. n., Stebbing, Das Tierreich, 21 (1), p. 687. 1908, C. n., Bradley, Univ. Cal. Publ. Zool., 4, p. 230. 1924-5, C. n., Behning, Int. Rev. Hydrobiol., 12, p. 228 ; 13, p. 46. 1924, C. n., Spandl, S. B. Akad. Wiss. Wien., 133, pp. 476, 500. 1928, C. n., Behning, Binnengewasser, 5, Leben des Wolgas, p. 122.

Distribution. Caspian Sea, Black Sea, R. Volga for $232 \mathrm{~km}$. from the mouth.

\section{Corophium Chelicorne G. O. Sars.}

[Sars, G. O., 1895, p. 299, pl. 22.]

1906, C. c., Stebbing, Das Tierreich, 21 (1), p. 687. 1908, C. c., Bradley, Univ. Cal. Publ. Zool., 4, p. 229. 1924, C. c., Martynov, Russk. Gidrobiol. Zh., p. 210. 1924, C. c., Spandl, S. B. Akad. Wiss. Wien., 133, pp. 476, 500. 1925, C. c., Behning, Int. Rev. Hydrobiol., 12, p. 228, 13, p. 46. 1928, C. c., Behning, Binnengewasser, 5, Leten das Wolgas, p. 122. 1929, C.c., Buchalowa, Zool. Anz., 85, p. 254.

Distribution. Caspian Sea, Black Sea, R. Volga for $232 \mathrm{~km}$. from the mouth.

4a. Corophium chelicorne G. O. Sars, praenatio fluviatile Martynov.

1924, C. c., prn. f. Martyrov, Annu. Mus. Zool. Acad. St. Petersb.

Distribution. R. Don.

\section{Corophium spinulosum G. O. Sars.}

[Sars, G. O., 1896, p. 481, pl. 12, f. 18-25.]

1906, C. s., Stebbing, Das Tierreich, 21 (1), p. 688. 1908, C. s., Bradley, Univ. Cal. Publ. Zool., 4, p. 229. 1924, C. 8., Spandl, S. B. Akad. Wiss. Wien., pp. 476, 500.

Distribution. Caspian Sea. 


\section{Corophium robustum G. O. Sars.}

[Sars, G. O., 1895, p. 304 (as C. robustum); pl. 23, f. 10-16 (as C. bidentatum)].

1896, C. r., Sowinski, Mem. Soc. Nat. Kiew., 15, p. 376. 1906, C. r., Stebbing, Das Tierreich, 21 (1), p. 689. 1908, C. r., Bradley, Univ. Cal. Publ. Zool., 4, p. 230. 1924, C. r., Spandl, S. B. Akad. Wiss. Wien., pp. 476, 500.

distribution. Caspian Sea, Black Sea.

\section{Corophium mucronatum G. O. Sars.}

[Sars, G. O., 1895, p. 307, pl. 24, f. 1-7.]

1896, C. m., Sowinsky, Mem. Soc. Kiew., 15, p. 375. 1906, C. m., Stebbing, Das Tierreich, 21 (1), p. 689. 1908, C. m., Bradley, Univ. Cal. Publ. Zool., 4, p. 230. 1924, C. m., Spandl, S. B. Akad. Wiss. Wien., pp. 476, 500.

distribution. Caspian Sea.

8. Corophium curvispinum G. O. Sars.

8a. C. c. var. Devium Wundsch.

8b. C. c. subsp. sowinskyi Martynov.

8c. C. c. prænatio fluviatilis Martynov.

[Sars, G. O., 1895, p. 302, pl. 23, f. 1-9, and Wundsch, H. H., 1915, p. 56, pl. 1-7, f. 1-9.]

1895, C. c., Sars, Bull. Acad. Sci. St. Petersb., Ser. 5, 3, p. 302, pl. 23. 1906, C. c., Stebbing, Das Tierreich, 21 (1), p. 690. 1908, C. c., Bradley, Univ. Cal. Publ. Zool., 4, p. 230. 1911, C. c., Beling, Arb. Biol. Dnjeper. Sta. Kiev., 1, p. 114. 1912, C. c. v. d., Dershavin, Arb. Ichth. Kasp.-Wolg. Fisch. in Astrachan, 2, Pt. 5. 1912, C. d., Wundsch, Zool. Anz., 39, p. 729, f. 1-16. 1913, C. d., Wundsch, Z. Fisch., 14, p. 136, f. 1. 1914, C.c. and C.c.f.d., Behning, Zool. Jb., 37, p. 385, f. A-N. 1914, Cyrtophium spongicola, Welitchkovsky, F. d. dist. Walonyki. Gouv. Woronege. Charkof, 12. 1915 , C.c. and C.c.f.d., Wundsch, S. B. Ges. Naturf. Fr. Berl., No. 3, pp. 56-81, Pl. 4, 5, Text-f. 1-9. 1919, C. c.. Wundsch, Arch. Hydrobiol. Plankt., 12, p. 693. 1923, C. c. f. d., Kulmatycki, Arch, Rybact. Polsk., 4. 1923, C. c. f. d., Schlienz, Arch. Hydrobiol., 14, p. 429. 1924, C. c., Behning, Int. Rev. Hydrobiol., 12, p. 228. 1924 (a), C. c. prn. f., Martynov, Russk. Gidrobiol. Zh., 3, p. 213 . 1924 (b), C. $c$. subsp. s. and C. $c$. subsp. s. prn. d., Martynov, Annu. Mus. Zool. Acad. Sci. Leningrad, 25, p. 49. 1925, C. c. f. d., Kulmatycki, Arch. Rybact. Polsk. 1925, C. c., Medwedewa, Arb. Biol. Wolga. Sta., 8, pp. 105-115. 1927, C.c., Stephensen, Vidensk. Medd. Naturh. Foren. Kbh., 84, p. 142. 1928, C.c., Behning, Russk. Gidrobiol. Zh., 7, p. 263. 1928, C. c., Behning, Binnengewasser, 5, Leben des Wolgas. 1929, C. c., Stephensen, Die Tierwelt der Nord und Ostsee, 14, x, f., pp. 168-70, f. 40. 1930, C. c. f. d., Kulmatycki, Frag. Faun. Mus. Zool. Polon., 1, No. 5. 1930, C. c., Wolski, Frag. Faun. Mus. Zool. Polon., 1, p. 152. 1931, C. c. f. d., Kulmatycki, Frag. Faun. Mus. Zool. Polon., 1, No. 11. 1931, C. c. f. d., Kulmatycki, Verh. Int. Vereinig. Limnol. Stuttgart., 14, p. 429. 1935, C. c. f. d., Crawford, Nature, 136, p. 685.

This variable, adaptable, and widely distributed species is found in salt, brackish, and fresh water, and several varieties have been described. Martynov $(1924, b)$ restricts the use of the name curvispinum to specimens from the Caspian Sea, and employs a new name, subsp. sowinskyi, for specimens from the Black Sea. The name devium of Wundsch he applies to specimens from the $\mathrm{R}$. Don, and rivers to the west of it, and considers these to form a "praenatio" of subsp. sowinskyi. He did not examine specimens from the Volga. The praenatio fluviatilis from the R. Oskol 
is described by Martynov (1924, a) from the figures of Welitchkovsky (1914), who named his specimens Cyrtophium spongicola n. sp.

This complicated scheme has not been adopted by any other writer. Wundsch regards $C$. curvispinum as an inhabitant of the Caspian Sea and Black Sea, and uses the name C. curvispinum forma devium for examples from fresh water; other authors follow this plan, or use the name $C$. curvispinum for all specimens.

Good accounts of the local races of this species are given by A. Behning (1914) (Caspian, Volga delta, Volga at Saratow, Black Sea, Dnieper at Kiev) and H. H. Wundsch (1919) (Caspian, Dnieper at Kiev, Muggelsee, near Berlin).

Distribution. Caspian Sea (type locality) and the Volga to $2,772 \mathrm{~km}$. from the mouth ; Black Sea and lowland courses of Danube, Dnieper and Don; rivers emptying into the Baltic and North Sea (Niemen to Elbe) : also two lakes in the Caucasus. England: River Avon at Tewkesbury ; Crawford (1935).

Wolski (1930) gives the most up-to-date list of localities. Wundsch (1915) states that $C$. c. var. devium was at that time spreading rapidly in Germany, moving through canals and rivers from East to West, usually downstream. The English specimens (13 in number, both sexes) were identified by Prof. Wundsch as C. curvispinum var. devium.

ECOLOGY. Forming tubes on weeds in sluggish waters. C. c. var. devium is restricted to the freshwater lowland courses of rivers.

\section{Corophium monodon G. O. Sars.}

[Sars, G. O., 1895, p. 309, pl. 24, f. 8-16.]

1906, C. m., Stebbing, Das Tierreich, 21 (1), p. 690. 1908, C. m., Bradley, Univ. Cal. Publ. Zool., 4, p. 230. 1924, C. m., Spandl, S. B. Akad. Wiss. Wien., 133, pp. 476, 500.

distribution. Caspian Sea.

\section{Corophium maeoticum Sowinski.}

[Sowinski, W., 1898, Bull. Acad. Sci. St. Petersb., v. 8, p. 362, pl. 1, f. 1-5.]

1906, C. m., Stebbing, Das Tierreich, 21 (1), p. 740. 1924 (a), C. m., Martynov, Russk. Gidrobiol. Zh., 3, p. 210. 1924 (b), C. m., Martynov, Annu. Mus. Zool. de L'Acad. Sci. Rus., 25, p. 44.

Distribution. Sea of Azov. Penetrates some way into the R. Don, and builds tubes on Cordylophora lacustris and Plumatella repens, presumably in fresh water (Martynov, 1924,b).

\section{Corophium salmonis Stimpson.}

[Bradley, J. C., 1908, p. 235, f. 20-35, 38, 39.]

1906, C. s., Stebbing, Das Tierreich, 21 (1), p. 692.

Distribution. California: Puget Sound. Alaska: Karluk beach and estuary (from stomachs of sockeyes and cohos-Oncorhynchus nerka and O. kisutch). 


\section{Corophium spinicorne Stimpson.}

[Bradley, J. C., 1908, p. 287, f. 1-19, 36, 37.]

1888, C. s., Stebbing, Rep. Voy. Challenger, 29, p. 303. 1906, C. s., Stebbing, Des Tierreich, 21-(1), p. 692. 1925, C. s., Essig, Pan. Pacif. Entom., 1, p. 189.

Distribution. San Francisco Bay (salt-marshes): San Francisco water supply - one specimen, from fresh water, recorded by Essig and identified by C. R. Shoemaker of the Washington Museum.

\section{Corophium affine Bruzelius.}

[Sars, G. O., 1894, p. 618, pl. 221, f. 2.]

1862, C. a., Bate, Cat. Brit. Mus., p. 283. 1901, C. a., Elliott, Laurie and Murdoch, F. Fl. and Geol. Clyde Area, Glasgow, p. 343. 1905, C. a., Scott, Proc. Roy. Phys. Soc. Edinb., 16, pp. 172-3. 1906, C. a., Stebbing, Das Tierreich, 21 (1), p. 688. 1908, C. a., Bradley, Univ. Cal. Publ. Zool., 4, p. 230. 1927, C. a., Stephensen, Vidensk. Medd. Naturh. Foren. Kbh., 84, p. 139. 1929, C. a., Stephensen, Die Tierwelt der Nord und Ostsee, 14, x. f., pp. 168-9, f. 40. 1929, C. a., Stephensen, Zoology of Faroes, Copenhagen, XXIII, Marine Crustacea Amphipoda, pp. 1-40. 1933, C. a., Stephensen, Fauna Aretica, 6, p. 372 .

Distribution. Europe: Lofoten Is. to N. Friesian Is.; Skagerrak, and N. Kattegat; Scotland (Firth of Forth, Firth of Clyde, Shetland Is.) ; Faroe Islands. A record by Sowinsky (1898) from the Bosphorus, in Mém. Soc. Kiev, v. 15, p. 457, is based on a single specimen which was not figured, and was lost. It probably did not belong to this species.

ECOLOGY. C. affine burrows in the sea-bottom in depths of from 8-60 m. (Stephensen, 1929).

\section{Corophium aculeatum Chevreux.}

[Chevreux, E., 1908, pp. 70-72, f. 1-3.]

1911, C. a., Chevreux, Mem. Soc. Zool. Fr., 23, pp. 270-1.

Distribution. Bône (Algeria) dredged from soft grey mud in about $8 \mathrm{~m}$. of water.

identification. The male is distinguished by the great length of its rostrum from all other males in this section.

\section{Corophium annulatum Chevreux.}

[Chevreux, E., 1908, pp. 73-74, f. 4, 5.]

1911, C. a., Chevreux, Mem. Soc. Zool. Fr., 23, p. 271.

Distribution. As for C. aculeatum.

I have seen specimens identified by M. Chevreux. The broadly truncate rostrum and the outgrowth near the base of the inner edge of antenna I, segment 1, distinguish the adult male of this sfecies from all others in this section. 
16. Corophium Runcicorne Della Valle.

[Della Valle, A., 1893, p. 13, pl. 4, f. 7 ; pl. 8, f. 1-16, 19.]

1906, C. r., Stebbing, Das Tierreich, 21 (1), p. 689. 1908, C. r., Bradley, Univ. Cal. Publ. Zool., 4, p. 230. 1908, C. r., Chevreux, Bull. Soc. Zool. Fr., 33, p. 69. 1911, C. r., Chevreux, Mem. Soc. Zool. Fr., 23, p. 270. 1925, C. r., Chevreux, Bull. Soc. Zool. Fr., 50, p. 392. 1925, C. r., Chevreux and Fage, F. de France, 9, p. 365, f. 373 . 1925, C. r.. Schellenberg, Meeresf. W. Afrikas, 3, p. 191.

Distribution. Mediterranean Coasts: Naples, Bonifacio, Algiers, Bosphorus.

ECOLOGY. Burrows in sand in $15-80 \mathrm{~m}$.

IDENTIFICATION. The male is uniquely characterized by a curved, forwardly-pointing outgrowth from the base of the outer edge of antenna I, segment 1 .

17. Corophium rotundirostre Stephensen.

1915, C. r., Stephensen, Rep. Danish Oceanogr. Exped. Medit., 2, D. 1, p. 52, fig. 33.

Distribution. Mediterranean, off the coast of Sicily $\left(37^{\circ} 29^{\prime}\right.$ N., $12^{\circ} 34^{\prime}$ E.).

ECOLOGY. Burrowing in clay in $112 \mathrm{~m}$.

identification. Only two specimens were found (1 male, 1 female) and these both lacked antenna II. In other features they rather resembled C. annulatum, but were far bigger (4-5.5 mm., compared with 1.5-2 mm. in length).

\section{Corophium triaenonyx Stebbing.}

[Stebbing, T. R. R., 1904, Spol. Zeyl., v. 2, p. 25, pl. 6 A.]

1906, C. t., Stebbing, Das Tierreich, 21 (1), p. 740. 1908, C. t., Bradley, Univ. Cal. Publ. Zool., 4, p. 229. 1922, C.t., Chilton, Trans. Proc. N.Z. Inst., 53, pp. 232-3.

Distribution. Ceylon: L. Negombo.

ECOLOGY. Forming tubes under bark of coconut piles, in brackish water.

IDENTIFICATION. The male is not distinctive, but the female is characterized by the spines on antenna II, segment 4, which lie in a row of six or so along the lower edge, and a row of two on the inner surface.

\section{Corophium rioplatense Giambagi.}

[Giambagi, D., 1926, An. Mus. Nac. Buen. Aires, v. 34, p. 137, f. 1-3.] 1934, C. r., Shoemaker, Proc. Biol. Soc. Wash., 47, p. 23.

Distribution. Rio de la Plata.

ECOLOGY. Forming tubes on bivalve shells in fresh water.

identification. The male is not distinctive, but the female is characterized by a laminar expansion running the length of antenna II, segment 4, and bearing four or five spines. This expansion is particularly pronounced distally. 


\section{Section B.}

Urosome segments fused. Uropods I and II inserted in notches in the lateral margins of the urosome.

This section contains eight species, two of which (C. sextoni and $C$. insidiosum) are here described as new species. I have examined all except C. californianum. All are of small or moderate size, from 2 to $6 \mathrm{~mm}$. in length. The male of $C$. bonelli and the female of $C$. californianum are unknown : in the other six species the 4th peduncular segment of antenna II is unlike in the two sexes. C. crassicorne burrows in muddy sand, the remainder build tubes on hydroids, etc. C. bonelli, C. acherusicum, and $C$. insidiosum are widely distributed. The section is confined to water of nearly full salinity, except for $C$. insidiosum which has frequently been found in salinities of about $15 \%$.

\section{KEY TO SPECIES.}

1. Antenna II, segment 4 with a complex terminal tooth reaching nearly to end of segment 5 . . . . . . . . C. californianum ô

Antenna II, terminal tooth on segment 4 absent, or not reaching middle of

2. Eye-lobes acute, eyes poorly developed; animal burrowing in muddy sand
Eye-lobes rounded or truncate, eyes well developed; animal building tubes upon sessile objects

3. Antenna II, segment 4 with a large and a small terminal tooth Antenna II, segment 4 armed with a row of 6-8 large spines .

4. Antenna II, segment 4 with a large terminal tooth and a smaller one above $(\hat{\sigma}) 5$ Antenna II, segment 4 armed only with spines (오 ‥ . . 9

5. Rostrum lanceolate, about $\frac{1}{3}$ as long as basal segment of antenna I . . $\quad 6$ Rostrum triangular, short .. . . . . . .

6. Antenna I, segment 1 with blunt outgrowth on inner surface about opposite middle of rostrum . . . . . . . . . insidiosum ô Antenna I, basal segment with no such outgrowth . . . . C C. uenoi ô

7. Antenna II, segment 4 very setose . . . . . . . C. tuberculatum Antenna II, segment 4 with few, short setæ . $\quad$. $\quad$. $\quad . \quad$. $\quad$. 8

8. Antenna I, flagellum 5-segmented, <2nd segment; antenna $\dot{I I}$, segment 4 with 2-3 spines, segment 5 without processes . . . . C. sextoni Antenna I, flagellum 7-10-segmented, >2nd segment; antenna II, segment 4 without spines, segment 5 with 2 processes . . C. acherusicum ô

9. Antenna II, segment 5 without spines . $. \quad . \quad . \quad . \quad$ C. tuberculatum Antenna II, segment 5 with 1 or 2 spines $\quad . \quad . \quad . \quad . \quad . \quad . \quad . \quad 10$

10. Antenna II, segment 4 with spines set in a single row $\quad . \quad . \quad . \quad . \quad . \quad . \quad 11$ Antenna II, segment 4 with all spines, except the terminal, set in pairs : 12

11. Antenna II, segment 4 with 4-6 spines set on a flange . . . C. sextoni 우

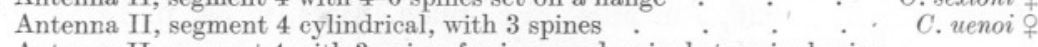

12. Antenna II, segment 4 with 3 pairs of spines, and a single terminal spine .

Antenna II, segment 4 with 2 pairs of spines, and a single terminal spine . 13

13. Antenna I, segment 1 with the basal spines on inner and lower edges sharply recurved

Antenna r, with these bonelli o

This key can only be satisfactorily used for adult specimens. 


\section{Corophium crassicorne Bruzelius.}

Figure 4, A-F.

[Sars, G. O., 1894, p. 615, pl. 220.]

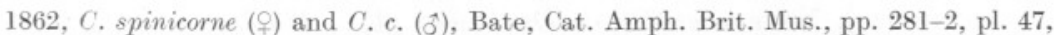
f. 5, 6. 1888, C.c., Robertson, Trans. Nat. Hist. Soc. Glasg., 2, p. 66. 1898, C.c., Sowinski, Bull. Acad. Sci. St. Petersb., Ser. 5, 8, pp. 361-2. 1901, C.crassicornis, Elliott, F. Fl. and Geol. Clyde Area, p. 342. 1905, C. c., Scott, Proc. R. Phys. Soc. Edinb., 16, p. 172. 1906, C. c. (part), Stebbing, Das Tierreich, 21 (1), p. 690 ("found in Norfolk in almost fresh water," refers to C. lacustre). ? 1907, C. c., Norman, Ann. Mag. Nat. Hist., Ser. 7, 20, p. $369 . \quad 1908$, C. c., Bradley, Univ. Cal. Publ. Zool., 4, p. 230. 1914, C. c., Walker, Spp. of Amph. and Isop. taken by Runa July-Aug., 1913. 1923, C. c., Stephensen, Vidensk. Medd. Naturh. Foren. Kbh., 78, p. 73. 1925, C. c., Chevreux and Fage, F. de France, 9, p. 367, f. 375. 1927, C. c., Stephensen, Vidensk. Medd. Naturh. Foren. Kbh., 84, p. 139. 1929, C. c., Stephensen, Die Tierwelt der Nord-und Ost-See, 14, x. f., pp. 168-9, f. 40. 1929, Stephensen, Zoology of Faroes, Copenhagen, XXIII, Marine Amphipoda Crustacea, pp. 1-40. 1931, C. c., Elmhirst, Proc. Roy. Soc. Edinb., 51, No. 21, p. 171. 1931, C. c. (part) Plymouth Marine Fauna, 2nd Ed. 1931, C. c., Schijfsma, Tijdschr. Ned. Dierk. Ver., Ser. 3, No. 2, p. 168. 1932, C.c., Elmhirst, Glasg. Nat., X, No. 2, pp. 56-62. 1933, C. c., Stephensen, Fauna Arctica, 6, p. 372. 1934, C. c., Shoemaker, Proc. Biol. Soc. Wash., 47, p. 24.

Papers by Hoek $(1879,89)$ placed by Stebbing $(1906)$ in the synonymy of this species refer rightly to $C$. acherusicum.

Distribution. Europe: "from Jan Mayen (not Greenland and Iceland) along the European coasts to Bosporus"-Stephensen (1929). America: Bay of Fundy to Gardiner's Bay, Long Island; Chichagof Harbour, Athi, Alaska - Shoemaker (1934).

ECOLOGY. C. crassicorne burrows in muddy sand, and is usually obtained by dredging in shallow water. At Fairlie Sands, Millport, in the Clyde, it is found between tidemarks, and I have seen a collection of 1,017 specimens taken from an area of $0 \cdot 25 \mathrm{sq}$. metres from this locality.

I have dredged $C$. crassicorne at Plymouth in small numbers from Cawsand Bay, from White Patch, from near the Melampus buoy, and in the mouth of the Yealm. These grounds are all in shallow water (about $5 \mathrm{fm}$.) and the first three lie in Plymouth Sound. All four grounds are chiefly composed of fine sand and silt. Soil from Cawsand Bay contains $78 \%$ of fine sand and $19 \%$ silt, according to a determination made by the method of Allen (1899-Journ. Mar. Biol. Assoc., N.S., V, pp. 378-380). For soil from Melampus these figures are $37 \%$ and $6 \%$, the remainder being chiefly formed by large stones between which this muddy sand is packed. Flourishing beds of Zostera marina (a plant also associated with $C$. crassicorne in the Clyde-Robertson, 1888) once existed at Cawsand, White Patch, and the mouth of the Yealm; in 1934-5 these had become much reduced.

Most of the records in Plymouth Marine Fauna (1931) probably refer to $C$. bonelli, as the localities given are suitable for this species and not C. crassicorne. Further I have found in the Laboratory at Plymouth jars of $C$. bonelli labelled $C$. crassicorne. The records of Percival (1929) 
must refer to $C$. acherusicum (p. 617), which I found abundant on the Neille Point buoys.

BREEDING aND SEX-RAtio. Ovigerous females were present in the collections made in April and July, but not in those made in October (26 specimens), November (9), or December (4). Of 67 specimens whose sex was determined $19.5 \%$ were males. Of 200 specimens examined from collections sent me from Millport, and collected in August, 1931, 49\% were males.

identification. The small eyes and sharp eyelobes are features not found in other species of this section. In the female the form of antenna II, segment 4, is distinctive at all ages ; it is almost crescent-shaped in section, with the concavity facing inwards and upwards.

GROWTH-CHANGES. Juvenile females have fewer spines on the antennae than adults. In juvenile males the rostrum is less pronounced, and the spines on antenna I, which are short and blunt in the adult, are long and sharp : antenna II, segment 4, is relatively stouter than in the adult, and bears a few small spines on the ventral surface basally, which later disappear; there are no outgrowths on antenna II, segment 5. These changes are illustrated in Fig. 4, A-F. The larger specimen was $2.9 \mathrm{~mm}$. long from rostrum to telson, and antennæ I and II were $53 \%$ and $70 \%$ of this length. For the other specimen these figures were $2.6 \mathrm{~mm}$., $39 \%$ and $45 \%$.

\section{Corophium bonelli G. O. Sars.}

Figure 2, $\mathrm{H}-\mathrm{O}$.

HISTORICAL. In 1830 Milne-Edwards gave the name C. bonelli to an Amphipod from an unknown locality, but his description is not precise enough for assured identification, and none of his specimens survive. In 1894 G. O. Sars described and figured female specimens of a Corophium collected in south-west Norway, which he called by Milne-Edwards' name. Neither of these authors makes mention of a male.

Though females continued to be found in great numbers, the first male to be assigned to this species was one collected in Alaska with three females, and described, but not figured, by Shoemaker (1920). In 1924 Stephensen figured one of a number of males from the east coast of Denmark, making mention in his description of the small differences between these males and the specimen examined by Shoemaker.

C. pseudacherusicum was named by Schellenberg (1931) from a few females from Tierra del Fuego. He noted a few slight differences between his specimens and the figures of Sars.

examination of specimens. Thanks to the kindness of Dr. Huus of Oslo, Dr. Stephensen of Denmark, Prof. Schellenberg of Berlin, Dr. Fanning of Hamburg, Prof. Fage of Paris, Prof. Brian of Genoa, Prof. 
Dohrn of Naples, and Dr. Shoemaker of Washington, I have been able to examine specimens from many parts of the world, as noted in Appendix I (a) and (b).

I found that :-

(1) The females could be separated into two forms, never both present in the same collection. The small but constant differences between them are tabulated in Table II.

(2) Of these forms none was ever found with males in the same collection, even when present in thousands (except occasionally with males of C. sextoni, C. acherusicum, or C. acutum). A list of specimens of this form is given in Appendix I (a).

(3) To this form belonged all the females identified with $C$. bonelli by G. O. Sars. They are 164 in number, from four localities in southwest Norway, and are now at the Oslo Museum.

Sars did not set apart a type, and therefore I have considered all these specimens as co-types of the species. They resemble his figures and description so closely that I have no doubt, in view of the evidence of locality, that figures, description and specimens belong all to a single species, which I shall call $C$. bcnelli G. O. Sars, to avoid confusion with Stephensen's use of the name C. bonelli (M.-Edw. ?) G. O. Sars. There are, however, some slight differences, in features important for diagnosis, between Sars' figures and his specimens, and I have therefore redescribed C. bonelli on page 613 .

(4) To this form also belong the 15 specimens from Tierra del Fuego, on which was based Schellenberg's description of C. pseudacherusicum. Schellenberg used Sars' figures and description for comparison with his specimens. From these he drew up the list of differences between his species and $C$. bonelli, with the exception of the difference in shape of the basal joint of the mandibular palp, for the observation of which he compared his specimens with some from the Kieler Bucht, Germany. These I have seen, and found to belong to the other form, which I have described on page 615 as $C$. insidiosum n.sp.

The specimens from Tierra del Fuego are indistinguishable from those of Sars. I therefore regard C. pseudacherusicum as a synonym of $C$. bonelli G. O. Sars.

(5) The other form of female was almost always found with males, which usually made up $20-40 \%$ of the whole number in a collection (see Appendix I (b)). Adult males were not distinguishable from that figured by Stephensen (1924) as C. bonelli (M.-Edw. ?) G. O. Sars, and all certainly belonged to one species, as the whole range of variation was sometimes represented in single large collections. 


\section{TABLE II.}

Antenna I, joint 1, spines on lower edge

Antenna I, joint 1, spines on inner edge

Antenna II, joint 5, spines on lower edge

Mandibular palp, basal joint

* Gnathopod I, palm

Gnathopod II, accessory teeth on dactyl

*Uropod I, spines on inner edge of peduncle
C. bonelli G. O. Sars (ovigerous 오).

Norway (G. O. Sars det.), England, France,

Denmark, East Coast of N. America.

\section{C. insidiosum n. $\mathrm{sp}$. (ovigerous 우).}

Plymouth, Venice, Denmark, Germany.

3 or 4, rarely 5; all straight.

1-3; basal 1 not, or slightly, recurved.

1 ; in 2 out of 400 specimens, 2.

Not distinctly prolonged.

Nearly straight: spines slender, of uniform size.

Very oblique ; spines stout, those near the hinder edge far the longest.

2 , rarely 1 .

3 , rarely 2 or 4 .

3 or 4 , well spaced.

1 , terminal.

* These distinctions are based on an investigation of $C$. bonelli from Norway and Plymouth and $C$. insidiosum from Plymouth and the Lake of Venice only.

The specimens described by Shoemaker (1920) do not fit into this scheme. I have not seen them, but Dr. Shoemaker has sent me excellent tracings of the most important features. Both sexes differ from $C$. insidiosum in having the basal joint of the mandibular palp much prolonged, and the dactyl of gnathopod II with only one accessory tooth. The other features of the male considered by Shoemaker (1934a) to be

\section{EXPLANATION OF FIGURE 2.}

A-E.-Corophium insidiosum n.sp.,, holotype $\times 52$.

A.-Antenna I, segment 1 from side.

B.-Antenna I, segment 1 from above.

C.-Antenna II.

D.-Gnathopod I, propod.

E.-Gnathopod II, dactyl.

F.- - paratype, Plymouth, mandibular palp $\times 250$.

G. -2 , L. of Venice, mandibular palp $\times 250$.

H-O.-C. bonelli G. O. Sars.

H-J.-Ovigerous + , Millbay, Plymouth, 22.vii.07.

H.-Mandibular palp $\times 250$.

I.-Antenna II $\times 38$.

J.-Antenna I, segment 1 and 2 , from above, $\times 38$.

K-M.-Ovigerous o, Tierra del Fuego, 30.x.1892, Hamburg Museum 10752 (co-type of C. pseudacherusicum), $\times 38$.

K.-Antenna II.

L.-Antenna I, peduncle, from side.

M.-Antenna I, from above.

N, O.-Ovigerous 9 , Norway (determined by Sars as C. bonelli), $\times 38$.

N.-Antenna I, from side.

O.-Antenna II.

P.-C. acherusicum da Costa, ㅇ, Neille Pt., Plymouth, 29.1.35, antenna II (setae omitted) with an exceptionally large number of spines, $\times 38$. 
REVIEW OF GENUS COROPHIUM.

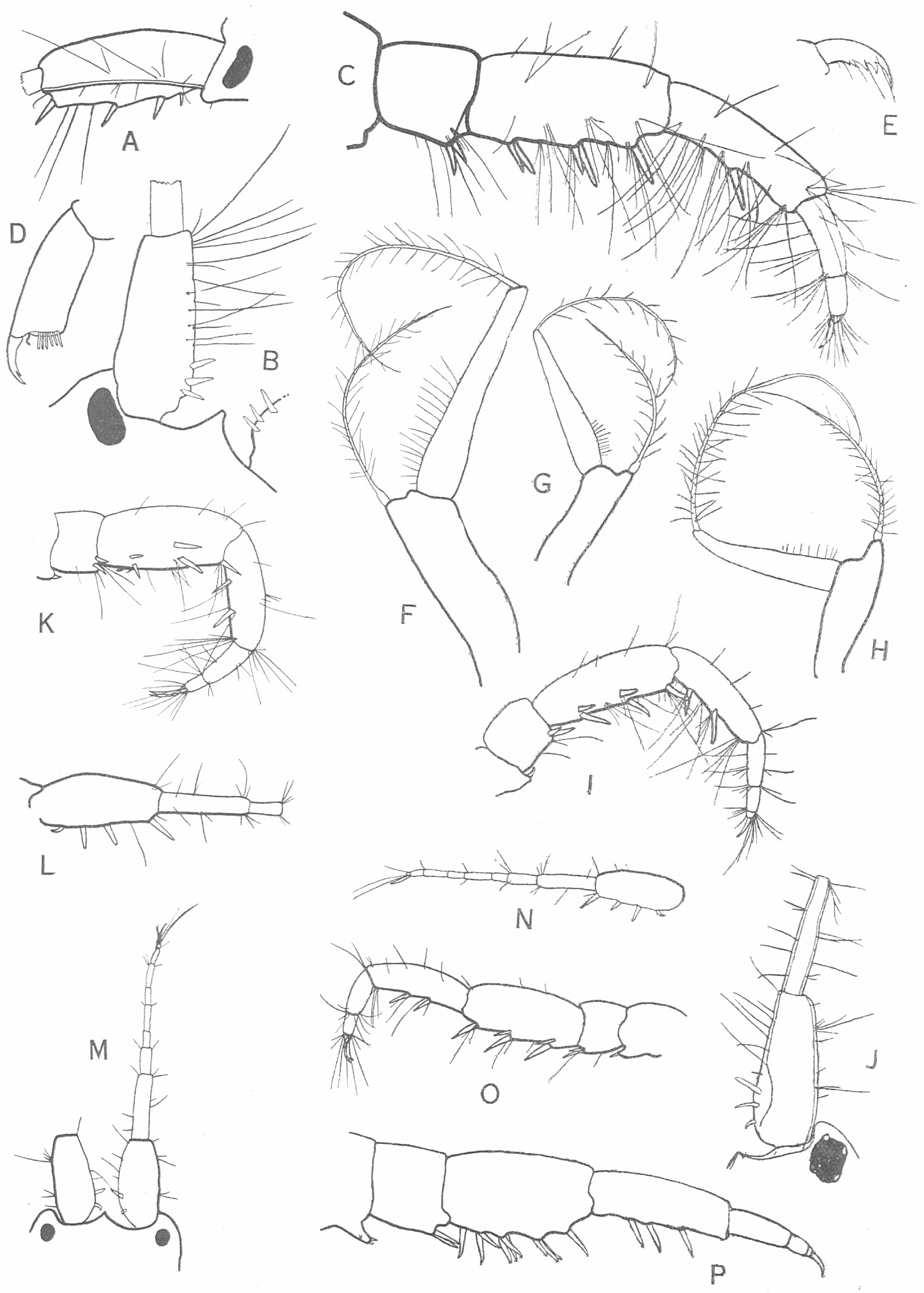

FIG. 2 . 
distinctive are also found in juvenile males of $C$. insidiosum, and the antennae of the female resemble those of $C$. insidiosum in the number and arrangement of spines. Until more material is obtained the precise status of these specimens must be uncertain. They certainly closely resemble $C$. insidiosum in both sexes, but appear to be distinct.

REFEREnces. Owing to the confusion between $C$. bonelli and $C$. insidiosum it is frequently impossible to tell to which of these species a paper refers.

\section{References presumably applicable to $C$. bonelli only.}

? 1830, C. b., Milne Edwards, Ann. Sci. Nat., 20, p. 385. ? 1840, C. b., Milne Edwards, Hist. Nat. Crust., 3, p. 67. ? 1862, C. b., Bate, Cat. Amph. Brit. Mus., p. 282. ? 1873 , C. b., Parfitt, Trans. Dev. Ass. Sei. and Lit., 6, p. 249. 1879, C. crassicorne var., Hoek, Tijdschr. Ned. Dierk. Ver. IV, p. 118, Pl. 8, f. 9, 10. 1882, C. b., Sars, Vid. Selsk. Forh. Christ., No. 18, p. 112 . 1889, C. c., Walker, 3rd Rep. Higher Crust., L. M. B. C. distr. Liverpool, p. 211. ? 1893, C. b., Chevreux and Bouvier, Ann. Sci. Nat., Ser. 7, 15, p. 140. 1893, C. b., Della Valle, F. Fl. Neapel, 20, p. 368. 1894, C. b., Sars, Crust. Norway, 1, p. 616 , pl. 221, f. 1. ? 1897, C. b., Sowinski, Mém. Soc. Kiew, 15, p. 456 . ? 1900, C. b., Chevreux, E., Rés. Comp. Sci. Monaco, 16, p. 109. ? 1901, C. b., Elliott, Laurie and Murdoch, F. Fl. Geol. Clyde Area, Glasgow, p. 343. 1905, C. b., Scott, Proc. R. Phys. Soc. Edinb., 16, p. 172. 1906, C. b., Norman and Scott, Crust. Devon and Cornwall, p. 95. 1906, C. b., Stebbing, Das Tierreich, 21 (1), p. 691. ? 1907, C. b.. Norman, Ann. Mag. Nat. Hist., Ser. 7, 20, p. 369. 1910, C. b., Chevreux, Mém. Soc. Zool. Fr., 23, p. 271. 1914, C. b., Walker, Ann. Mag. Nat. Hist., Ser. 8, 13, p. 558. $1929, C . b$. , Stephensen, Zoology of Faroes, Copenhagen, XXIII, Marine Crustacea Amphipoda, pp. 1-40. 1930, C. b., Barnard, Brit. Ant. Terra Nova Exp., Nat. Hist. Crust., XI, p. 393. 1931, C. b., and C. crassicorne (part), Plymouth Marine Fauna, p. 197. 1931, C. pseudacherusicum, Schellenberg, Furth. Zool. Res. Swed. Antarct. Exp. 1901-3, No. 6, p. 258, f. 1932, C. cylindricum, Barnard, Disc. Rep. V, p. 244. 1933, C. b., Stephensen, Fauna Arctica, 6, p. 372.

References to C. bonelli and $C$. insidiosum, with confusion between the species.

1924, C. b., Stephensen, Vidensk. Medd. Naturh. Forening, Copenhagen, 78, pp. 7378, f. 3. 1924, C. b., Ussing, Tom. cit., pp. 69-72. 1925, C. b., Chevreux and Fage, F. France, 9, Amph., p. 369, f. 377. 1927, Stephensen, Tierwelt Nord und Ostsee, 14, x.f., pp. 168-9. 1931, C. b. and C. pseudacherusicum, Schellenberg, Furth. Zool. Res. Swed. Antaret. Exp., 6, p. 258. 1931, C. b., Schijfsma, Tijdschr. Ned. Dierk. Ver., Ser. 3, 2. pp. 168-70. 1932, C. b., Brian, Boll. Mus. Zool. Anat. Comp. Genova, 12, No. 52. 1934, C. pseudacherusicum, Shoemaker, Proc. Biol. Soc. Wash., 47, p. 26.

Table III shows my interpretation of the meaning given to the names C. bonelli and C. pseudacherusicum in certain recent papers.

\section{TABLE III.}

Paper.

Shoemaker (1920)

Stephensen (1924) .

Schellenberg (1931).

Brian (1932) .

Shoemaker (1934)
C. bonelli refers to :-

Sars' (1894) figures of C.b.,,$; 1 \hat{\jmath}$, $3 \circ$ from Alaska (sp. indet.).

Sars' figures of $C . b .$, , + ; $\widehat{0} \hat{0}$ and $+q$ of $C . i$. from Denmark.

Sars' figures of $C . b .$, 우; 우우 of $C . i$. from Germany.

$\delta \delta^{t}$ and $\phi ᄋ$ of $C . i$. from L. of Venice ; Sars' observations on sex-ratio of C. b.

As Shoemaker (1920)
C. pseudacherusicum refers to :-

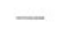

C. b. from Tierra del Fuego.

ôô of $C$. $i$. from Den. mark; 오 of $C . b$. from Tierra del Fuego and N. America. 
Brian's statement that $C$. bonelli is an example of "geographic parthenogenesis "is due to a confusion of this species with $C$. insidiosum. So is the observation by Shoemaker (1934a) that the form of the mandibular palp is different in the two sexes of C. pseudacherusicum.

Redescription of female of C. bonelli G. O. Sars (Fig. 2, H-O), from specimens from Norway named by G. O. Sars.

Length about $4 \mathrm{~mm}$. in ovigerous females. Rostrum short, triangular. Eyes black, well-developed. Eyelobes rounded.

Antenna $I$ : segment $1<2+3$, lower edge with three large, straight, equally spaced spines distally and one or two shorter, sharply recurved spines proximally; inner edge with one to three spines, proximal one short and sharply recurved; flagellum, 8-segmented in fully grown specimens.

Antenna $I I$ : segment 4 with a basal and a median pair of spines and a terminal single spine, on the lower edge ; segment 5 frequently with two spines of which the proximal is sometimes as large as the distal, sometimes smaller or absent even in the largest specimens - the distal spine is always present.

Mandibular palp, basal segment much prolonged beyond base of second segment. Gnathopod I, palm very oblique, with a row of stout spines of which those near the hinder edge of propod are far the largest ; dactyl with one small accessory tooth. Gnathopod $I I$, dactyl with two, or more rarely one, accessory tooth.

Urosome segments fused ; sides of urosome hollowed out at the insertion of uropods 1 and 2 .

The male is unknown. Since the female has been collected, often in thousands, from many parts of the world, it is very probable that reproduction in this species is normally parthenogenetic. This has never, however, been tested by rearing experiments. Parthenogenesis is known in Talitrus alluaudi Chevreux, and there is some evidence for it in Haustorius arenarius (Slabber), but it is certainly unusual in the Amphipoda. There is no reason to suppose that it occurs in any other known species of Corophium.

Distribution. See Appendix I (a).

OCCURRENCE AT PLyMOUTH. In the Laboratory at Plymouth are several collections made between 1889 and 1911, chiefly from Millbay Channel, but also from Asia Shoal, West Channel, and between Drake's Island and Mount Edgecumbe. Each of these contains several hundreds of specimens.

In 1934 from several dredgings on these grounds I obtained only five specimens, four from New Grounds and one from near Drake's Island. The place of $C$. bonelli was taken by $C$. sextoni n.sp., a species not present in the earlier dredgings. 
F C. bonelli builds tubes of mud on hydroids, etc., in water usually of full salinity. Breeding females are present in collections made at Plymouth in April, July, August, and October.

IDENTIFICATION. This species has often been confused with C. crassicorne and $C$. acherusicum. C. crassicorne is easily distinguished by its burrowing habits, the pointed eyelobe and by antenna II, segment 4, which in the female is expanded along its lower edge into a broad flange on which about eight spines are set in a row. Many of the distinctions between $C$. acherusicum and $C$. bonelli tabulated by Chevreux (1911) and Stephensen (1924) do not hold good for specimens of $C$. bonelli as redescribed here. The species are, however, distinct, and ovigerous females may be identified from Table IV. Younger specimens of either species have fewer spines.

\section{TABLE IV.}

Antenna I

Antenna I, segment 1

Antenna I, segment 1, inner and lower edges

Antenna II, segment 4

Pereiopod 7

\section{C. bonelli 오.}

$>$ antenna II, peduncle.

$<2+3$.

Basal spines sharply recurved.

5 spines, arranged 2, 2, 1 .

Basal joint $<$ propod.
C. acherusicum ㅇ. . $<$ antenna II, peduncle. $>2+3$.

All spines straight.

7 spines, arranged $2,2,2,1$. Basal joint $>$ propod.

VARIATION AND GROWTH CHANGES. As indicated in the redescription of this species on page 613 the number of spines on the antennal segments is not constant even in adults : in juveniles several spines are usually absent, especially the proximal spines of antenna I, and antenna II, segment 4 . In very small specimens $(c a .1 .5 \mathrm{~mm}$.) the proximal spine of antenna II, segment 5, is missing, and it frequently does not develop at all. Adult specimens are common in which the proximal spine is smaller than the distal, or in which it is absent from one antenna and present on its fellow. The percentage of ovigerous females in which it was found varied in collections from different localities, but not in correlation with latitude. The highest figure was 77 (from Plymouth), and the lowest 20 (from Trondhjem Fjord, Norway); however, figures greater than 70 were obtained from some Norwegian collections. Occasional specimens bear an additional spine beside the median pair on antenna II, segment 5, but the number is far less variable than in $C$. acherusicum. The number of accessory teeth on the dactyl of gnathopod II is usually two in ovigerous females and one in small specimens. 


\section{Corophium insidiosum n.sp.}

Figure 2, A-G.

DESCRIPTION OF FEMALE Holotype (Fig. 2, A-E). West Wharf, Millbay, Plymouth, 8.v.35, ovigerous.

Length $4.5 \mathrm{~mm}$. Rostrum pointed, short. Eyelobes rounded, elongate. Eyes black, well developed.

Antenna $I$ : about $30 \%$ of total length; segment $1<2+3$; lower edge with four straight spines, proximal one small, and a few long setae ; inner edge with three straight spines near base, several long setae distally; outer edge with scattered short setae ; segment 2 cylindrical, with several tufts of long setae; flagellum 7 -segmented.

Antenna II : scarcely longer than antenna I; segment 4 with 5 spines on lower edge - a basal and a median pair and a single terminal spinebesides many long setae; segment 5 with one median spine, and many long setae; flagellum 3-segmented.

Mouth-parts and limbs in general like those of C. bonelli. Mandible, palp with basal segment not prolonged. Gnathopod $I$, palm almost square, with six slender spines of uniform size on each face; dactyl with a minute accessory tooth. Gnathopod II, right dactyl (figured) with four accessory teeth; left dactyl with the more usual number, three. Pereiopod 7, basal segment oval $=$ propod in length .

Urosome as in C. bonelli. Uropod I, peduncle with one terminal spine on inner edge. Telson trapezoidal, with a wide terminal furrow, bordered with hooked spines.

Description of male Paratype. West Wharf, Millbay, Plymouth, 8.v.35.

Length $3.5 \mathrm{~mm}$. Rostrum spear-shaped, reaching nearly half-way along antenna I, segment 1 ; depressed at tip.

Antenna $I$ : about $50 \%$ total length; segment 1 , lower edge with a keel bearing one small terminal spine, and a few long setae; inner edge with only a few short setae - between these edges on the inner face a symmetrical blunt process opposite a point between the middle and tip of rostrum ; outer edge with scattered short setae : segment $2=$ segment 1 , narrowed at base, with a keel below bearing 16 long setae, rounded above with scattered setae of medium length : segment $3<\frac{1}{2}$ segment 2 ; flagellum 10-segmented, < segments $1+2$.

Antenna II : about $60 \%$ total length; segment 4, very stout, with a single large terminal ventral tooth, above which is a smaller single tooth ; with only a few setae: segment 5, cylindrical, lower edge with a uniform series of eight tufts of long setae : flagellum, 3-segmented, basal segment with a row of five tufts of long setae.

Other features as in female. 
I have not figured the male, since all charactors of importance are excellently drawn by Stephensen (1924).

Distribution. See Appendix I (b).

ECOlOgy. C. insidiosum like $C$. bonelli builds tubes of mud on weeds or hydroids; it appears, however, to frequent as a rule water that is less saline. The most nearly marine conditions under which I have found it at Plymouth are at Tinside, and at Millbay Pontoon and West Wharf. These are subject to a considerable diminution in salinity when the Tamar is running full. Millbay Inner Basin is an enclosed brackish pool. The buoys at Bull Point and Neille Point lie some miles up the Tamar Estuary. Chelson Meadow is reclaimed land: the ditches are brackish, filled by land drainage and occasionally by salt water coming over the sea-wall. Here Corophium insidiosum was found in numbers, building tubes on Ruppia maritima in the most saline ditches, that is to say those nearest the sluice which opens into the Plym Estuary. In the same collections Sphaeroma hookeri (Isopoda) was abundant, and a few Melita palmata and Leptocheirus pilosus (Amphipoda) wcre present. A hundred yards from the sluice the numbers of Corophium were much reduced, and it was associated with large numbers of Sphaeroma hookeri and Gammarus chevreuxi.

Ussing (1924) observes that the optimum salinity for $C$. bonelli in the Mariagerfjord is $13-18 \%$. I have seen his specimens, and found them to be $C$. insidiosum. The Italian and German localities also appear to be estuarine rather than marine.

IDENTIFICATION. The very long rostrum of the male is not found elsewhere in this section except in C. uenoi, and in Shoemaker's undetermined specimens from Alaska. The outgrowth on the inner surface of antenna I, segment 1, is absolutely distinctive.

The arrangement of spines on the antennae of ovigerous females is sufficient for identificaticn.

\section{Corophium uenoi Stephensen.}

1932, C. u., Stephensen, Annot. Zool. Jap., 13, p. 494-8, f. 3, 4.

DisTRIBUTION. Japan, in a tidal pool, presumably a tube-builder.

IDENTIFication. This species is very close to $C$. bonelli and $C$. insidiosum, from both of which it is distinguished by the female having only three spines, set in a longitudinal row, on antenna II, segment 4. In the type specimen brood-lamellae were developed, and presumably this arrangement of spines is typical of adult females. I have seen the male and cannot distinguish it from juvenile males of $C$. insidiosum; from adult males it is distinguished by the absence of an outgrowth on the inner surface of antenna I, segment 1 . 


\section{Corophium acherusicum Costa.}

Figure 2, P.

[Della Valle, A., 1893, p. 364, pl. 1, f. 11 and pl. 8, f. 17, 18, 20-41.]

1862, C. a., Bate, Cat. Brit. Mus., p. 282. 1873, C. cylindricum, Smith and Verrill, Rep. U.S. Comm. Fish., 1, p. 370. 1879, C. crassicorne, Hoek, Tijdsehr. Ned. Dierk. Ver. 4, p. 115, pl. 5, f. 16; pl. 8, f. 4-8. 1880, O. bonelli (), C. crassicorne (ठ)), Sowinsky, Les Amph. du Golfe Sebastopol. Kiev,, pp. 18-20, pl. 3, f. 3, 4. 1889, C. crassicorne, Hoek, Tijdschr. Ned. Dierk. Ver., Ser. 2, 2, p. 230. 1893, C. cyl., Della Valle, F. Fl. Neapel, 20, p. 376. 1900, C. a., Chevreux, Result. Camp. Sei. Monaco, 16, p. 109. ? 1904, C. cyl., Holmes, Bull. U.S. Bur. Fish., 24, p. 521, figs. 1905, C. cyl. (part), Paulmier, F. C., Bull. N.Y. St. Mus., 91, Zool., 12, p. 167 (see notes on literature below). 1906, C. a., Stebbing, Das Tierreich, 21 (1), p. 692. 1908, C. acheruzicum, Bradley, Univ. Cal. Publ. Zool., 4, p. 230. 1908, C. a., Chevreux, Bull. Soc. Zool. Fr., 33, p. 69. 1911, C. a., Chevreux, Mém Soc. Zool. Fr., 23, p. 271. ? 1914, C. cylindricus, Stebbing, Proc. Zool. Soc. Lond., p. 341. 1914, C. a., Walker, Ann. Mag. Nat. Hist., Ser. 8, 13, p. 558. 1916, C. a. (part), Barnard, Ann. S. Afr. Mus., 15, p. 272 (see notes on literature below ; see also C. acutum). 1918, C. cyl., Kunkel, Bull. Conn. Geol. Nat. Hist. Surv., p. 171, f. 52. 1923, C. a. Stephensen, Vidensk. Medd. Naturh. Foren., 78, p. 73. 1925, C. a., Chevreux, Bull. Soc. Zool. Fr., 50, p. 392. 1925, C. a., Chevreux and Fage, F. de France, 9, p. 368, f. 376. 1925, C. a., Schellenberg, Meeresf. W. Afrikas, 3, p. 191. 1928, C. a., Cecchini, Acc. Fisio. Crit. Siena (10), 3, p. 309. 1929, C. crassicorne, Percival, J. Mar. Biol. Assoc., 16, p. 81. 1931, C. crassicorne (part), Plymouth Marine Fauna, p. 197. 1931, C. a., Schijfsma, Tijdschr. Ned. Dierk. Ver., Ser. 3, 2, pp. 168-170. 1932, C. bonelli, Barnard, Disc. Rep., V, p. 244. 1934, C. a., Shoemaker, Proc. Biol. Soc. Wash., 47, pp. 24-5. 1935, C. a., Cecehini and Parenzan, Pub. Staz. Zool. Nap., 14, p. 227.

NOTES ON LITERATURE. Barnard (1916) records C. acherusicum from S. Africa. He describes antenna II, segment 5, in the male as bearing " in small specimens up to $2.5 \mathrm{~mm}$., a well-marked tooth on lower margin about $\frac{1}{3}$ from base or sometimes nearly in the middle, in other and larger specimens without a tooth and much more sparsely setose." The smaller specimens are $C$. acutum, the larger $C$. acherusicum, and both these species are represented in collections from Durban sent by Barnard to the British Museum.

The figure given by Paulmier (1905) must be referred to C. tuberculatum Shoemaker, though the urosome segments have been drawn separate in error. Through the kindness of Dr. Stoner of the New York Museum I have been able to examine some of Paulmier's specimens; both $C$. acherusicum and C. tuberculatum were present in tubes labelled C. cylindricum by Paulmier.

Distribution. Europe: S. England (Plymouth, Thames Estuary*); Coasts of France and Holland; Mediterranean. Africa: N. Coast from Suez Canal to Senegal, Durban Bay, ${ }^{*}$ Dar-es-Salaam. America: Baffin's Bay to Brazil, ? Falkland Is., Cuba,* Alaska.* Asia: Hong Kong.* New Zealand: Lyttelton Harbour.*

ECOLOGY. C. acherusicum forms tubes on weed and hydroids in shallow water, usually in harbours, and especially on floating objects such as buoys,

\footnotetext{
* Specimens examined in British Museum.
} 
rafts, and pontoons. The Sheerness specimens are from fouling on a ship's bottom.

occurrence at Plymouth. Buoys and rafts: Tinside bathing raft; buoys at Neille Point, Saltash, Barn Pool; Millbay Pontoon. Intertidally in small numbers at Neille Point Mussel Bed. It was most abundant on the Neille Point buoy where thousands were obtained from a breffit of weed, and least common on Millbay Pontoon where it was outnumbered by C. acutum, C. sextoni, and C. insidiosum.

iDENTIFICATion. Normal ovigerous females bear seven spines on antenna II, segment 4, arranged 2, 2, 2, 1. Occasional specimens bear up to four additional spines on this segment either alongside an original pair of spines, or between two pairs. I have seen such specimens from Plymouth, Sheerness, the Lake of Venice, and Alaska. In some, antenna II, segment 5, bore three spines in a row. (See Fig. 2, P.)

Adult males may be known by the following combination of characters : rostrum short; antennae scarcely setose ; antenna II, segment 5 with a small process near the base and a large blunt process terminally.

GROWTH-CHANGES. In the female the number of antennal spines, and of accessory teeth on the dactyl of gnathopod II, increase with age.

In the male there is a progressive deterioration of spines in number and size, and an appearance of processes on antenna II, segment 5, as shown in Table V.

TABLE V. (C. acherusicum, male).

Antenna I, segment 1, spines on lower edge Antenna II, segment 4, spines near base Antenna II, segment 5, spines .

Antenna II, segment 5, processes

Gnathopod II, dactyl, accessory teeth Pereiopod 7, carpus inner edge

BREEDING AND SEX-RATIO. Most of the females found in August (1935) and September (1934) were ovigerous ; in January (1935) adult

$\begin{array}{cc}\text { Juvenile } & \text { Adult } \\ 2-2 \cdot 5 \mathrm{~mm} . & 3-4 \mathrm{~mm} . \\ 3-4 & 1-4 \\ 1-2 & 0 \\ 0-2 & 0 \\ 0 & \text { small basal and } \\ & \text { large terminal. } \\ 1-2 & 2-3\end{array}$

nearly straight strongly convex

\section{EXPLANATION OF FIGURE 3.}

A-F.- - holotype.

Corophium sextoni n.sp.

A.-Antenna II, $\times 50$.

B.-Antenna I, segment 1 from inner side, $\times 50$ (setae not drawn on inner or outer edge).

C.- - Head from above, $\times 50$.

D.-Mandibular palp, $\times 100$.

E. -Gnathopod II, dactyl, $\times 50$.

F.-Urosome, $\times 50$.

G. H. $-\hat{\jmath}$ paratype, $\times 50$.

G.--Antenna II.

H.-Uropods I and II. 


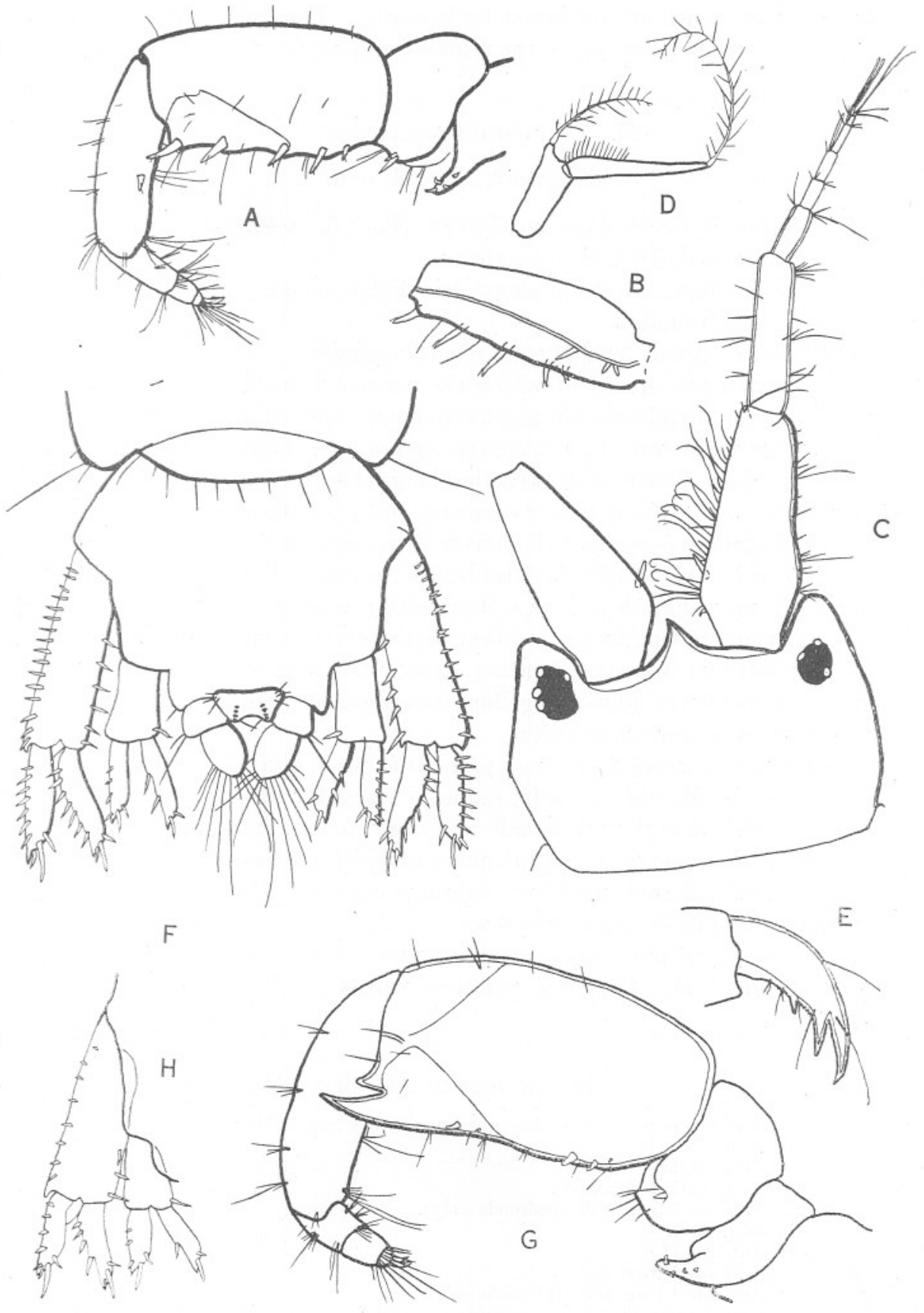

FIG. 3. 
females were much outnumbered by juveniles. Both sexes were present in all collections I examined, the female being rather the commoner.

\section{Corophium sextoni n.sp.}

Figures $3, \mathrm{~A}-\mathrm{H} ; 4, \mathrm{G}-\mathrm{H}$.

DESCRIPTION OF female holotype (Fig. 3, A-F). Winter Shoal, Plymouth Sound, 18.x.34, ovigerous.

Length $4.5 \mathrm{~mm}$. Rostrum short, triangular, acute. Eye large bleck. Eyelobes long, rounded.

Antenna $I$ : about $30 \%$ of total length ; segment $1>2+3$; lower edge convex, with five spines of which the proximal one is very short and recurved, the distal ones progressively longer and straighter, two setae; inner edge with two short recurved spines near base, beyond these a straight longer spine and 20-30 rather long setae; outer edge with several short setae, and tufts of longer ones at $\frac{2}{5}$ and $\frac{3}{4}$; segment 2 with scattered setae; flagellum 5-segmented, shorter than segment 2.

Antenna II : about $35 \%$ of total length ; segment 4 about twice as long as broad, pear-shaped in cross section with the lower edge produced into a flange running lengthwise and bearing five straight spines, increasing in length distally; segment 5 rather stout, with a short straight median spine on the lower edge; flagellum 3-segmented; antenna as a whole with few setae, and those short.

Mouth-parts, gnathopods, and pereiopods resembling in general those of C. bonelli. Mandibular palp, segment 1 slightly produced terminally. Gnathopod I, dactyl with small accessory tooth; proped with palm convex, oblique, set with several spines of which the posterior are largest, Gnathopod II, dactyl, with two subsidiary teeth. Pereiopods 5 and 6 . spines on carpus short, in two rows.

Urosome segments fused, lateral border emarginate at insertion of uropods I and II. Uropod I, peduncle with five to six spines on inner

\section{EXPLANATION OF FIGURE 4.}

A-F.-Corophium crassicorne Bruzelius from Fairlee Sands, Millport, $\times 50$.

A-C.-Adult $\hat{o}$.

A.-Antenna II.

B.--Antenna I from above.

C.-Antenna I from side (peduncle only).

D-F.-Juvenile $\hat{o}$.

D.-Antenna II.

E.-Antenna I from above.

F.-Antenna I from side (peduncle only).

G, H.-Corophium sextoni n.sp., ô paratype, $\times 50$.

G.- - Head from side.

H.-Head from above. 
REVIEW OF GENUS COROPHIUM.

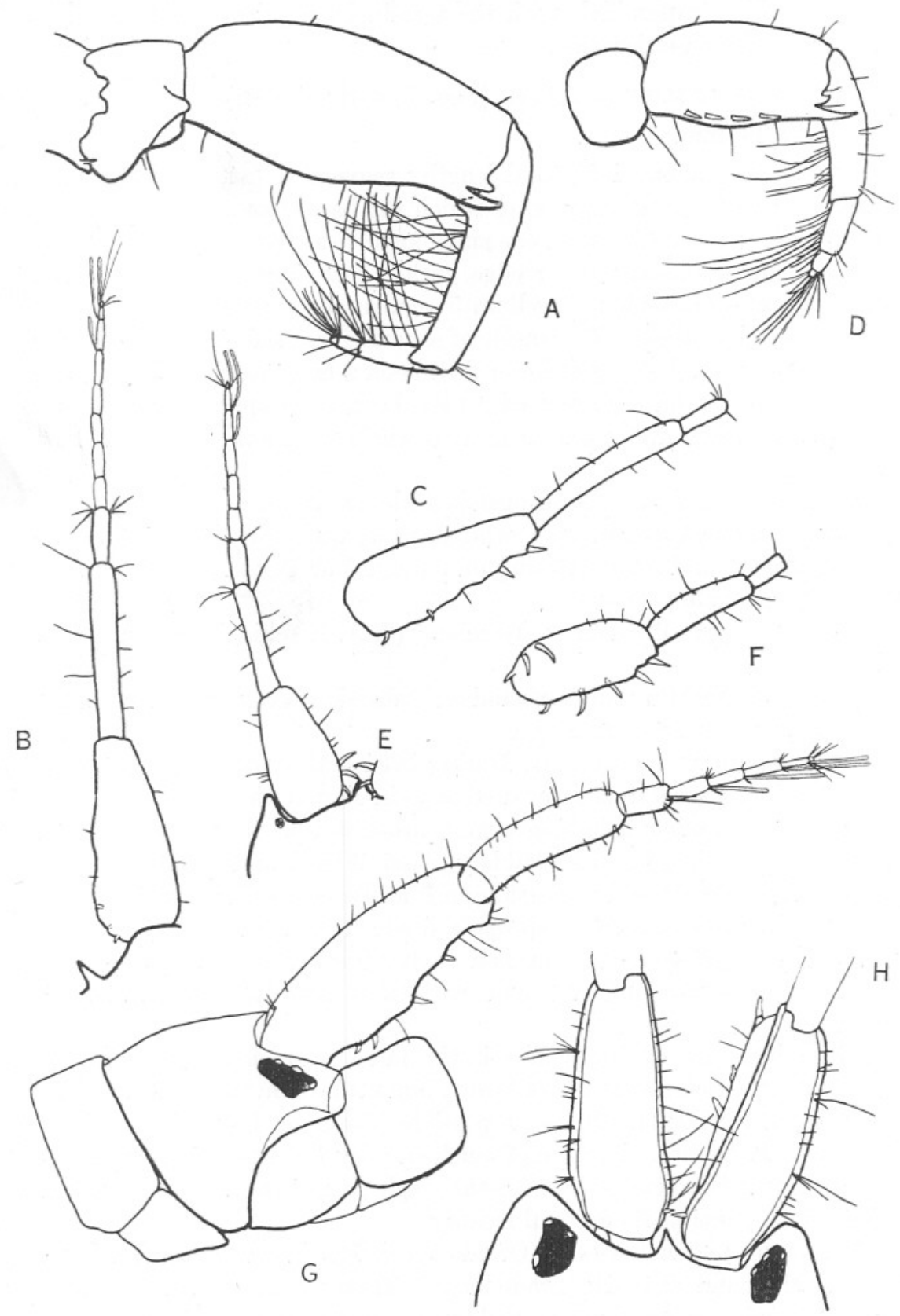

FIG. 4.

NEW SEIIIES.-VOL. XXI. NO. 2. MARCH, 1937. 
edge. Telson trapezoidal, with the terminal emargination bordered by four denticles on either side.

DESCRIPTION OF MALE PARATYPE (Figs. 3, G-H ; 4, G-H).

Length $4.0 \mathrm{~mm}$.

Antenna $I$ : about $40 \%$ total length; segment $1>2+3$; lower edge convex with five small spines, of which the basal two are recurved, and a few setae; inner edge with one small spine near base, and several setae beyond, mostly short; outer edge with a few short setae; segment 2 with a few short setae; flagellum 5-segmented=segment 2 .

Antenna $I I$ : about $55 \%$ length of animal ; segment 4 less than twice as long as broad, bearing at lower distal end a large tooth with a smaller tooth above it; on the lower edge two short, stout spines or processes ; flagellum 3-segmented; antennae as a whole with few setae, and those short.

Urosome as in female, but appendages less spinose.

Colour of paratypes in life: whitish grey, with two slaty bars across each segment, and slaty marking on antennae and head; sexes similar. Eggs, bright pale yellow.

Distribution. Plymouth; Wembury (J. A. Kitching) ; off mouth of Tagus.*

ECOLOGY. Building tubes of mud on hydroids, sponges, weed from just above low-water mark to $25 \mathrm{fm}$.

OCCURRence at Plymouth. During 1934-5 this was the commonest species of the genus in shallow dredgings in Plymouth Sound, especially if stones or Laminaria holdfasts were brought up. It was also found intertidally at Tinside and Millbay West Wharf, and on the floating pontoon at Millbay, and the bathing raft at Tinside. An unusual habitat was the carapace of a Maia squinado, dredged in $25 \mathrm{fm}$. off Rame Head, on which about 40 specimens had built their tubes. C. acutum and. C. insidiosum were often found with this species, but in smaller numbers.

The abundance of this species is the more surprising since it is not present in the rich collections of Corophium made from the same dredging grounds in 1895-1911. It seems possible, therefore, that it is not indigenous at Plymouth. In spite of much enquiry I am unable to find any record from elsewhere, except for the single female from Portugal ; and so I cannot guess at its original locality.

SEX-RATIO AND BREEDING. Of 240 specimens in one collection from Plymouth Sound 99, or $41 \%$, were males. There was no evidence of much seasonal variation in this ratio. Ovigerous females were found in February to December. The proportion of egg-bearing females was high from May

* 1 ㅇ in Copenhagen Museum; Dana Station 4155, 12.6.1930. 
to October, but fell off in November and December and was very small in February and March.

VARLATION. The females begin to breed at a length of 3.5 to $4 \mathrm{~mm}$., and attain a length of $5 \cdot 5$ to $6.0 \mathrm{~mm}$. The number of spines on the antennae is more variable than in $C$. bonelli or $C$. insidiosum. The following figures were obtained from 15 ovigerous females :

Antenna I, segment 1, inner edge. 1-3 spines ; mean $2 \cdot 5$.

, , , lower edge. $4-7 \quad,, \quad, \quad 5 \cdot 3$,

Antenna II, segment 4, ,, , , $4-6 \quad, \quad, \quad,, \quad 4 \cdot 6$.

GROWTH CHANGES. In the female the number of spines on the antennae increases with age. In the male the spines on all antennal segments decrease in size, but not apparently in number; and the degradation is never so complete as in C. acherusicum or C. crassicorne. Antenna II, segment 4, always remains stout and does not become elongated in the adult males as in these two species.

identification. The female may be identified from antenna II, segment 4, which cannot be confused except with that of $C$. crassicorne. The large eye and rounded eyelobe will distinguish it from this species.

In the male the shortness and sparseness of the setae on the antennae is characteristic of $C$. sextoni and $C$. acherusicum. In adult males of $C$. acherusicum, however, antenna I has 7-10 segments in the flagellum, and in antenna II, segment 4 , is elongate and bears no spines.

\section{Corophium tuberculatum Shoemaker.}

[Shoemaker, C. R., 1934a, pp. 29-30.]

1905, C. cylindricum, Paulmier, Bull. N.Y. State Mus., 91, Zool., 12, p. 167, f. 37 (see above: $C$. acherusicum-Notes on Literature).

Distribution. America: Nantucket to S. Carolina.

ECOLOGY. This species is found in oyster-washings, etc., from the mouth of rivers and in harbours.

\section{Corophium Californianum Shoemaker.}

1934, C. c., Shoemaker, J. Wash. Ac. Sci., 24, No. 8, pp. 359-60, f. 2.

One male specimen only is known, collected from the holdfast of waterlogged kelp dredged in $48 \mathrm{fm}$. in Montery Bay, California.

\section{Section C.}

Urosome segments fused. Uropods I and II inserted below urosome, not in notches in its lateral margins.

This section contains five species of small or moderate size $(2-6 \mathrm{~mm}$.), 
none of which was known to Stebbing (1906). I have seen all except C. louisianum and C. baconi. The female of $C$. louisianum is not known, and in $C$. simile antenna II, segment 4 , is similar in the sexes. In the remaining three species it is dissimilar. C. acutum, C. lacustre, and $C$. simile build tubes on hydroids, etc.; the habits of the other two species are unknown. All are marine except for $C$. lacustre which lives in water of a salinity from practically $0.0 \%$ to about $15 \%$ C. acutum and C. lacustre are widely distributed.

\section{KEY TO SPECIES.}

1. Margin of urosome consisting of a single convex curve

Margin of urosome consisting of two convex curves, separated by a distinct nick

2. Antenna II, segment 4 with one large curved terminal tooth, and a smaller tooth or lobe above it

Antenna II, segment 4 not so armed

3. Antenna II, segment 5 with no processes on lower margin

Antenna II, segment 5 with distinct processes on lower margin

4. Antenna I, segment 1 with a prominent, forward-pointing angular protuberance near base of inner surface Antenna I, not so armed

5. Antenna II, segment 5, process long, pointed, near middle of joint Antenna II, segment 5, process short, blunt, near base of joint

6. Antenna I, segment 1 with 2 spines on lower edge . Antenna I, segment 1 with no spines on lower edge

7. Antenna I, segment 1 with 1 spine: Antenna II, segment 4 with 2 spines

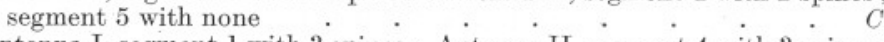

Antenna I, segment 1 with 3 spines: Antenna II, segment 4 with 3 spines ; segment 5 with one. Antenna II, segment 4 with no spines and two terminal teeth, segment 5 with a long hooked terminal tooth on inner margin

$$
\text { .louisianum ô }
$$

\section{Corophium acutum Chevreux.}

[Chevreux, E., 1908, p. 75, f. 6.]

1911, C. a., Chevreux, Mém. Soc. Zool. Fr., 23, p. 271. 1916, C. acherusicum (part), Barnard, Ann. S. Afr. Mus., 15, p. 272 (see also C. acherusicum). 1925, C. a., Chevreux and Fage, Faune de France, 9, p. 366, f. 359, 374. 1928, C. a., Schellenberg, Trans. Zool. Soc. Lond., XXII, p. 633. 1934, C. a., Shoemaker, Proc. Biol. Soc. Wash., 47, pp. 26, 27.

Distribution. Europe: France (R. Lannion, Concarneau), Monaco ; England (Plymouth and Studland). Africa: Suez Canal*; Durban.* America : Long Island Sound, Woods Hole, Cape May, Rio de Janeiro. New Zealand: Auckland.*

occurrence in england. Plymouth, and Studland, Dorset (Dr. J. A. Kitching, coll.). At Plymouth in 1934-5 this species was the commonest Corophium among sponges, coralline Algae and roots of Laminaria near low-water mark on the shores of Plymouth Sound. In these situations it outnumbered C. sextoni, C. bonelli, and C. insidiosum, but in

\footnotetext{
* Specimens examined in British Museum.
} 
shallow water dredgings ( $5-20 \mathrm{fm}$.) it was far less common than $C$. sextoni. In May, 1935, all these species except $C$. bonelli were abundant on the wharfs and pontoon of the Millbay Docks.

ECOLOGY. This species is a tube-builder, intertidally or in shallow water. It haunts harbours and the most saline reaches of estuaries.

SEX-RATIO AND BREEDING. Three collections, of over 100 specimens each, contained $42 \%$ and $45 \%$ (Plymouth) and $34 \%$ (Suez Canal) of males. As in C. acherusicum, C. insidiosum, and C. sextoni males appear to be slightly less common than females.

Egg-bearing females were found in February, March, May, and from July to November. The proportion of females with eggs to those without eggs was higher in the summer than in the winter, though some are probably to be found all the winter through.

\section{Corophium Lacustre Vanhöffen.}

[Vanhöffen, E., 1911, S. B. Ges. Naturf. Fr. Berl., p. 400, f. 1-4, and Sexton, E. W., 1912, Proc. Zool. Soc. Lond., p. 664, pl. 74, f. 13-17.]

1896, C. crassicorne, Scherren, Nature, 54, No. 1399, p. 367. 1966, C. crassicorne (part), Stebbing, Das Tierreich, 21, p. 691 ("found in Norfolk in almost fresh water "). 1907, C. grossipes (part), Gurney, Trans. Norfolk Norw. Nat. Soc., 8, pp. 423, 427 (part), 435 (part), Table II (part). 1917, C.l., Vanhöffen, S. B. Ges. Naturf. Fr. Berl., p. 113, f. 2. 1918, C.l., Hellén, Medd. Soc. Fauna Fl. Fennica, 45, p. 136. 1922, C. crassicorne, Tesch, Fl. F. der Zuiderzee, pp. 333-4, f. 6. 1923, C. l., Schlienz, Arch. Hydrobiol. Plankt., 14, p. 429. 1924, C. l., Spandl, S. B. Akad. Wiss. Wien., 133, p. 475. 1926, C. acutum var. chevreuxi, Poisson and Legueux, Bull. Soc. Zool. Fr., 51, pp. 320-5, f. 5, 6. 1927, C. l., Stephensen, Die Tierwelt der Nord-und Ost-See, 14, X, f., pp. 168-9, f. 40. 1931, C. l., Schijfsma, Tijdschr. Ned. Dierk. Ver., Ser. 3, 2, pp. 168-70. 1934, C. l., Shoemaker, Proc. Biol. Soc. Wash., 47, p. 27.

Distribution. Europe: Germany (Frisches Haff, Bremerhaven, Elbe); Finland (Borga); Holland (Zuiderzee) ; France (Canal de Caen) ; England (R. Thurne and Heigham Sound, Norfolk). America: Chesapeake Bay to Winyah Bay.

I have compared specimens from Germany (Vanhöffen), France (Le Roux), and America (Shoemaker), with those from Norfolk, and find them indistinguishable.

occurrence in England. 8.ix.35, River Thurne near Potter Heigham, Norfolk (two collections) and Heigham Sound, found by Mr. G. A. Steven abundantly among Cordylophora lacustris and on stems of Phragmites communis. The only other Crustacean present was Gammarus zaddachi, two specimens of which were present in one collection.

The specimens referred to by Scherren (1896) as C. crassicorne, and Gurney (1907) as C. grossipes (part), were found in the same localities. Their habits were the same as those of Steven's specimens, and very different from those of $C$. crassicorne or of $C$. volutator, of which $C$. grossipes is a synonym. None of these specimens remain. When they 
were collected $C$. lacustre was still undescribed, and this is the reason for the misidentification of specimens undoubtedly belonging to this species.

ECOLOGY. C. lacustre builds muddy tubes upon submerged plants or animals, especially Cordylophora lacustris. It inhabits water of low salinity. Schlienz (1923) states that the species extends in the Elbe from areas where the range of salinity is $0 \cdot 17$ to $0 \cdot 87$ parts of $\mathrm{NaCl}$ per thousand, to areas where this range is $0 \cdot 17$ to $20 \cdot 61$. In Norfolk it is known so far only from waters in which there is no tidal effect, but which are kept brackish by a subterranean salt-water table. Gurney (1907) records salinities up to $78 \mathrm{gm}$. per gallon $(1 \cdot 1$ parts $\mathrm{NaCl}$ per 1000$)$ in the River Thurne above the tidal reaches.

\section{Corophium simile Shoemaker.}

1934, C. s., Shoemaker, Proc. Biol. Soc. Wash., 47, pp. 28-9.

Distribution. America: Atlantic Coast, S. Carolina to Vineyard Sound, Mass. Found in sponges, or by washing oysters, or scraping piles in sheltered, but not estuarine, water.

\section{Corophium louisianum Shoemaker.}

1934, C. l., Shoemaker, Proc. Biol. Soc. Wash., 47, pp. 30-1.

Distribution. America: Atlantic Coast, Louisiana, and Missouri (only two specimens known: both ôô).

\section{Corophium Baconi Shoemaker.}

1934, C. b., Shoemaker, Journ. Wash. Sc. Sci., 24, No. 8, pp. 356-9, f. 1.

Distribution. America: Pacific Coast, off Peru and Southern California, and in the Behring Sea.

\section{ACKNowledgements.}

Throughout the course of this work I have benefited by the advice of Mrs. E. W. Sexton and of Dr. K. Stephensen, who have also kindly looked over this manuscript before it went to the printers. I wish to express my thanks to them, and to all those others who have helped me in ways recorded more precisely above.

\section{Doubtful References.}

The following names probably do not apply to species of Corophium.

Podocerus cylindricus, Say, 1818, J. Ac. Philad., 1 (2), p. 387 ; Bate, 1862, Cat. Amph. Brit. Mus., p. 256.

Corophium cylindricum, Stebbing, 1888, Rep. Voy. Challenger, 29, p. 104. 
Corophium quadriceps, Dana, 1852, P. Amer. Ac., 2, p. 219 ; Dana, 1853, 1855, U.S. Expl. Exp., 13 (2), p. 836, pl. 55, f. 8; Bate, 1862, Cat. Brit. Mus., p. 283, pl. 48, f. 7 (copied from Dana 1853-5) ; Stebbing, 1888, Rep. Voy. Challenger, 29, p. 255 ; Della Valle, 1893, F. Fl. Neapel, 20, p. 376 .

The following names probably refer to species of Corophium which cannot, however, be identified.

C. bidentatum, Marcusen, 1867, Arch. Naturges., 33, p. 360.

C. bonelli, Czerniawsky, 1868, Mat. Zoo. Ponticam: Comp., p. 96 ; Walker, 1909, Trans. Linn. Soc., 12, p. 343.

C. contractum, Stimpson, 1855, P. Ac. Philad., 7, p. 383 ; Bate, 1862, Cat. Brit. Mus., p. 282 ; Thomson, 1881*, Trans. Proc. N.Z. Inst., 13, p. 220 , pl. 8, f. 9 ; Thomson and Chilton, 1886*, Trans. Proc. N.Z. Inst., 18, p. 142 ; Della Valle, 1893, F. Fl. Neapel, 20, p. 374 ; Hutton, 1904, Index Faun. N.Z. London; Stebbing, 1906, Das Tierreich, 21 (1), p. 692.

C. crassicorne, Thomson and Chilton, 1886*, Trans. Proc. N.Z. Inst., 18, p. 142 ; Sowinski, 1898, Mem. Soc. Nat. Kiew., 15, p. 361 ; Hutton, 1904, Index Faun. N.Z., London; Chilton, 1922*, Trans. Proc. N.Z. Inst., 53, p. 229-223, f. 5.

C. cylindricum, Miers, 1880, Ann. Mag. Nat. Hist., Ser. 5, 5, p. 125 ; Bradley, 1908, Univ. Cal. Publ. Zool., 4, p. 230.

C. dentatum, Muller, 1864, Für Darwin, p. 51; Della Valle, 1893, F. Fl. Neapel, 20, p. 374 ; Stebbing, 1906, Das Tierreich, 21 (1), p. 692.

\section{LIST OF WORKS CITED}

(other than in the bibliography of species).

Bradley, J. C. 1908. Notes on two Amphipods of the genus Corophium from the Pacific Coast. Univ. Cal. Publ. Zool., Vol. 4, pp. 227-242, pls. 9-13.

Chevreux, E. 1908. Sur trois nouveaux Amphipodes méditerranéens appartenants au genre Corophium Latreille. Bull. Soc. Zool. Paris, Vol. 33, pp. 69-75.

Chevreux, E., and Fage, L. 1925. F. de France, Vol. 9, Amphipodes, pp. 363-369, figs. 359, 371-377.

Della Valle, A. 1893. F. Fl. Neapel. Vol. 20, Gammarini, pp. 362376 , pls. 1 (f. 11), 4 (7), 8 (1-41), 55 (58-60), 56 (2-6).

* From internal evidence it seems likely that Chilton (1922), and so also Thomson (1881), and Thomson and Chilton (1886) were referring to C. acherusicum. Chilton was unable to distinguish his specimens from Dutch ones of this species lent by Hoek (as C. crassicorne); and specimens of C. acherusicum from Lyttelton Harbour are in the British Museum. 
Hart, T. J. 1930. Preliminary notes on the bionomies of the Amphipod Corophium volutator Pallas. Journ. Mar. Biol. Assoc., N.S., Vol. XVI, pp. 761-789, 4 figs.

Sars, G. O. 1894. Crustacea of Norway, I, Amphipoda, pp. 612-619, pls. 219-221.

1895 and 1896. Crustacea Caspia, III, Amphipoda. Bull. Acad. Sci. St. Pétersb. Ser. 5, Vol. 3, pp. 275-313, pls. 17-24, and Vol. 4, pp. 481-484, pl. 12.

Shommaker, C. R. 1920. Rep. Canad. Arctic Exped. 1913-18. Vol. 7, pt. E, p. 22.

1934, a. The Amphipod genus Corophium on the east coast of America. Proc. Biol. Soc. Washington, 47, pp. 23-32.

- 1934, b. Two new species of Corophium from the west coast of America. J. Wash. Acad. Sci., 24, pp. 356-360, 2 figs.

Stebbing, T. R. R. 1906. Das Tierreich, Lief. 21 (1), Amphipoda Gammaridea, pp. 685-692, 740, f. 116-118.

Stephensen, K. 1929. Die Tierwelt der Nord und Ost-See, Vol. 14, x. f. Amphipoda, pp. 168-170, f. 40 (311-316).

Thamdrup, H. M. 1935. Beiträge zur Oekologie der Wattenfauna auf Experimenteller Grundlage. Medd. Komm. Havundersøg, Kbh. Ser. Fiskeri, Vol. X, No. 2, pp. 1-125, 125 figs.

Ussing, H. 1924. Biology of Corophium bonelli. Vidensk. Medd. naturh. Forening, Copenhagen, 78, pp. 69-72, figs.

Wundsch, H. H. 1915. Weitere beiträge süsswasserform von Corophium curvispinum. S. B. Ges. Natur. f. Fr. Berl., No. 3, pp. 56-81, pls. 4, 5 , text-f. $1-7$.

\section{APPENDIX I.}

List of Specimens Examined of C. Bonelli and C. insidiosum.

(a) C. bonelli.

Locality and date.

England, Plymouth

Wales, Tenby

Colwyn Bay

Scotland, Tobermory

Loch Swen
Source of specimens. Number of 90 . British Museum $\quad 100$

$1908 \quad$,. , 14

1895 Marine Biological

1905

1907

1911

1934

1880

1898

1913

1933 Association, Plymouth 100

G. I. C'rawford "

British Museum 1

,,,$\quad 7$

, ,,$\quad 6$

Dr. J.A. Kitching 133 
Locality and date.

Ireland, Valentia

Guernsey

Roundstone

France, Portrieux, Grandeamp, St. Vaast

Italy, Naples

Denmark, Lodshusene

,, No locality
Norway, Oslofjord*

Haugesund*

Bergenfjord*

Ris\%r*

Bergensfjord

Trondhjhemfjord

Solsvig

North America, East Coast $\dagger$

South America, Uschaia

Picton Is. $\$$
Punta Arenas:

500 miles E.N.E.

from Rio de

Janeiro

Falkland Islands
Source of specimens. Number of 9 .

British Museum

$$
3
$$

1896

1874

1906

,

,

Paris Museum $50-100$

Naples Museum

6

1878 Copenhagen Museum 20

,, , , 50-60

Oslo Museum 68

, , , 17

$,, \quad,, \quad 28$

B'ritish Museum $\quad 1$

1893

1908

,

Washington "Museum

1892

1892

1892

Hamburg Museum

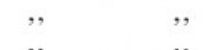

1913

British Museum

1926

In all these collections no $\hat{\sigma} \hat{o}$ were present.

(b) C. insidiosum.

Locality and date.

England, Plymouth :

Millbay Pontoon

,,
,,
,,
W. wharf

Tinside inner basin

Bull Point buoy

Neille Point buoy

Chelson Meadow

Denmark :

Mariagerfjord, Aamolle Oct. '22

Frederikshavn

Östersóen (near Graasten)

Germany, Kieler Bucht

Italy, Lake of Venice

America :

Source of specimens.

Number of 우아.

Number

of $\hat{\sigma} \hat{o}$.

$\begin{array}{rrrr}\text { 3.viii.34 G. I. Crawford } & 15 & 0 \\ \text { 3.ix.34 } & , & 25 & 7 \\ \text { 7.ix.35 } & , & 9 & 0 \\ \text { 8.v.35 } & , & 94 & 15 \\ \text { 8.v.35 } & , & 27 & 19 \\ 5 . \mathrm{ii} .35 & , & 2 & 0 \\ \text { 31.v.35 } & , & 0 & 1 \\ \text { 2.viii.35 } & , & 2 & 1 \\ 9 . v i i i .35 & , & 246 & 199\end{array}$

27.v.23

5.viii. 23

13.xii.34

Sept. '29

Oct. ' $29 \S$

$29 . \times .35 \|$

Oakland, San Francisco 2.ix.31
Copenhagen Museum 8

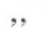

,

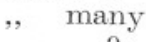

,$$
\text { , }
$$$$
\text { , } 3
$$

Prof. A. Brian 100

40

Copenhagen Museum 4
,, , 1
0

15

19

0

1

99

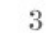

5

2

1

2

100

40

* Labelled by Sars as C. bonelli M. Edw.

$\dagger$ C. pseudacherusicum-Shoemaker (1934a).

$\ddagger$ C. pseudacherusicum-Schellenberg (1931).

$\S 4,097$ 우우, 1,244 우 0 -Brian (1932).

|| 1,492 우, 398 o 


\section{APPENDIX II.}

\section{The British Species of Corophium.}

Species.

C. volutator (Pallas)

C. arenarium n.sp.

C. curvispinum G. O. Sars var. devium Wundsch

C. affine Bruzelius

C. crassicorne Bruzelius

C. bonelli G. O. Sars

C. insidiosum n.sp.

C. acherusicum da Costa

C. sextoni n.sp.

C. acutum Chevreux

C. lacustre Vanhöfien
British localities, and habits.

Coasts of Great Britain and Ireland ; burrowing in intertidal mud flats, often in estuaries.

Leigh-on-Sea, Essex ; burrowing in sand between tide-marks.

R. Avon at Tewkesbury; building tubes of mud on weed and stones in fresh water.

From Forth and Clyde northwards; burrowing, below low-water mark.

Coasts of Great Britain; burrowing in muddy sand from just above low-water mark downwards.

Coasts of Great Britain and Ireland; building tubes on weed, etc., from low-water mark downwards.

Plymouth; building tubes on weed usually in brackish water.

Plymouth, Sheerness, New England Creek (Essex) (formerly, the creek is now shut in and brackish); building tubes on weed, etc., especially on rafts and buoys.

Plymouth; habits as in C. bonelli.

Plymouth, Studland (Dorset); habits as in $C$. bonelli.

R. Thurne and Heigham Sound, Norfolk; build. ing tubes, usually in clumps of Cordylophora lacustris in brackish (nearly fresh) water. 